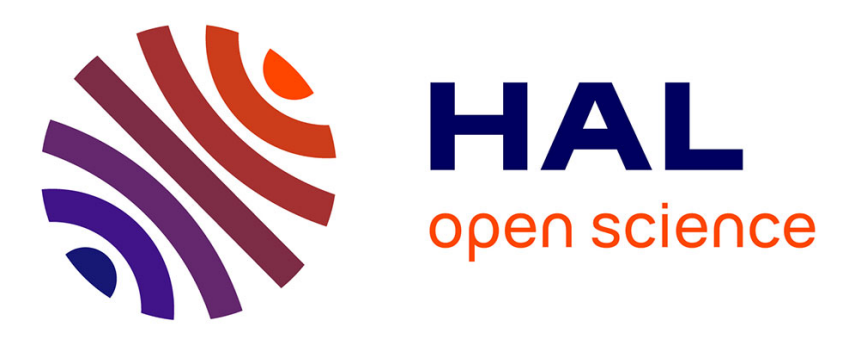

\title{
Modeling of trace gases from the 1998 North Central Mexico forest fire smoke plume, as measured over Phoenix
}

V. R. Kotamarthi, P. V. Doskey, S. R. Springston, P. Hyde, J. S. Gaffney, N. A. Marley

\section{To cite this version:}

V. R. Kotamarthi, P. V. Doskey, S. R. Springston, P. Hyde, J. S. Gaffney, et al.. Modeling of trace gases from the 1998 North Central Mexico forest fire smoke plume, as measured over Phoenix. Atmospheric Chemistry and Physics Discussions, 2006, 6 (2), pp.3227-3264. hal-00301206

\section{HAL Id: hal-00301206 https://hal.science/hal-00301206}

Submitted on 18 Apr 2006

HAL is a multi-disciplinary open access archive for the deposit and dissemination of scientific research documents, whether they are published or not. The documents may come from teaching and research institutions in France or abroad, or from public or private research centers.
L'archive ouverte pluridisciplinaire HAL, est destinée au dépôt et à la diffusion de documents scientifiques de niveau recherche, publiés ou non, émanant des établissements d'enseignement et de recherche français ou étrangers, des laboratoires publics ou privés. 
Forest fire smoke plume

\section{Modeling of trace gases from the 1998 North Central Mexico forest fire smoke plume, as measured over Phoenix}

V. R. Kotamarthi ${ }^{1}$, P. V. Doskey ${ }^{1}$, S. R. Springston ${ }^{2}$, P. Hyde ${ }^{3}$, J. S. Gaffney ${ }^{1}$, and N. A. Marley ${ }^{1}$

${ }^{1}$ Environmental Science, Argonne National Laboratory, 9700 South Cass Avenue, Argonne, IL 60439-4843, USA

${ }^{2}$ Brookhaven National Laboratory, Upton, NY, USA

${ }^{3}$ Arizona Department of Environmental Quality, Phoenix, AZ, USA

Received: 16 January 2006 - Accepted: 10 February 2006 - Published: 18 April 2006

Correspondence to: V. R. Kotamarthi (vrkotamarthi@anl.gov)

V. R. Kotamarthi et al.

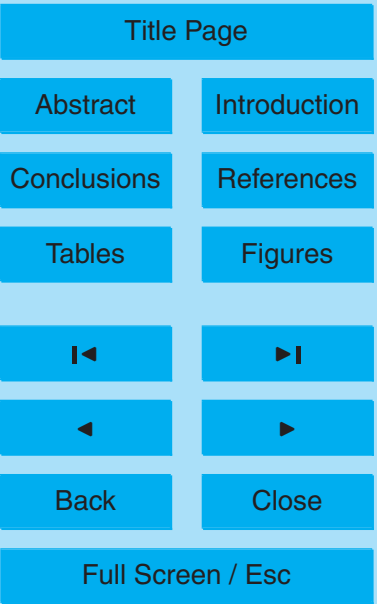

Printer-friendly Version

Interactive Discussion 


\section{Abstract}

Forest fires in North and Central America have been frequent and extensive over the past few years. Though much research has addressed the effects of forest fires in tropical South America and Africa on regional and global-scale oxidants, the same is

5 not true for North America. Here we show that one of the days during an intensive field campaign conducted over Phoenix, Arizona, in 1998 was substantially influenced by transport from forest fires in central and southern Mexico. We combined data collected from aircraft platforms, surface stations, and satellite with model results to establish that the origin of the air sampled over Phoenix on 20 May 1998, was from forest fires ico. We also investigated the effect of the smoke layer on hence photochemistry over a five-day travel period from the source region to Phoenix. The results show that a smoke layer could reduce photolysis rates of key tropospheric constituents significantly and decrease the oxidant formation rates during the first few days of the plume history. The ultimate effect of the smoke layer on the evolution of oxidants in the plume was, however, shown to be minimal.

\section{Introduction}

Biomass burning emissions profoundly affect air quality on local scales. The deterioration of air quality due to smoke includes reduced visibility and increases in $\mathrm{CO}$ and hydrocarbon mixing ratios in the immediate vicinity. These conditions can last several weeks to months, depending on the duration of the event. Biomass burning resulting from both anthropogenic activities (e.g., forest clearing, activities associated with agriculture) and natural events (e.g., lightning strikes in drought conditions) affects forested areas. Much attention has been focused on potential effects of large-scale events such as the massive burning of tropical rain forests (Fishman et al., 1991; Longo et al., 1999; Thompson et al., 2001). However, little is known about the short-term effects of forest fires on air quality in North America, particularly in urban and semi-urban ar-
Forest fire smoke plume

V. R. Kotamarthi et al.

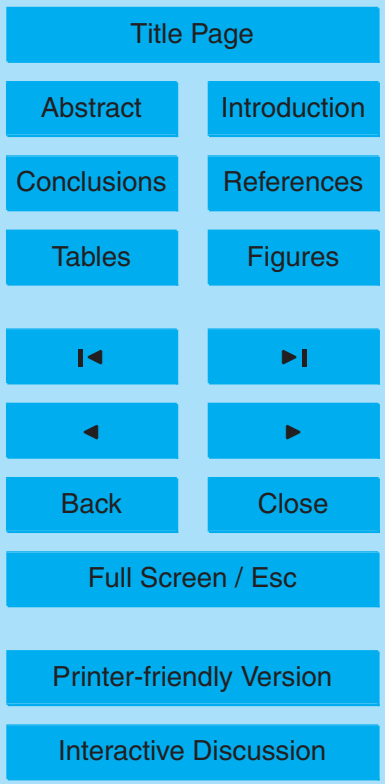

EGU 
eas (Wong and Li, 2002). The impact of such forest fires on ozone mixing ratios near the surface and throughout the tropospheric column over North America needs further investigation.

We had an opportunity, during the year 1998 over Phoenix, Arizona, to sample air 5 impacted by forest fires in North Central Mexico. The measurements were part of an intensive six-week study conducted in May and June, in and around Phoenix, as a part of a U.S. Department of Energy (DOE) Atmospheric Chemistry Program initiative in collaboration with the Arizona Department of Environmental Quality (ADEQ). Measurements of meteorological variables were made during this campaign to improve 10 simulations of the flow conditions in the region (Fast et al., 2001). Meanwhile, an exhaustive characterization of the chemical composition of the air was conducted from a small aircraft (Gulfstream G-1). Argonne ground-based monitoring stations augmented those operated by the ADEQ (Gaffney et al., 2002; Doskey et al., 2000).

Extensive forest fires reported in central and northern Mexico during April and May 15 of 1998 covered thousands of acres (Peppler et al., 2000). The plume from these fires reached as far north as Wisconsin. Ground-based measurements of the optical characteristics of the smoke plume were reported from the DOE Atmospheric Radiation Measurement Program's Southern Great Plains (SGP) site in Oklahoma, as well as in Texas and other southwestern U.S. states. Peppler et al. (2000) reported an increase in ozone and mixing ratios above $80 \mathrm{ppb}$ on $7,12,13,15,19,20$, and 22 May at the SGP site. They also observed increase in large particles (sizes greater than $10 \mathrm{~nm}$ ) in the atmosphere on 5, 8, 12, 16, 24, and 25 May. Aerosol single scattering albedos were highest on 10,14, and 18 May. It is difficult to attribute the increase in ozone at this location to the smoke event. Rather, the general southerly direction of the wind flow during this period is thought to have contributed to the observed ozone, because several highly polluted urban areas in Texas are directly south of the SGP site. During May and June 1998, thousands of acres of biomass are estimated to have burned. Here we focus on a set of trace gas measurements made during the Phoenix 1998 experiment that show the presence of the plume over Phoenix and provide some indications of its

\section{Forest fire smoke} plume

V. R. Kotamarthi et al.

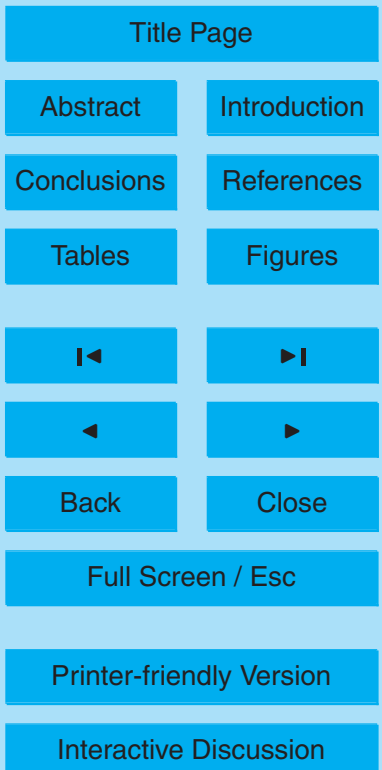


effect on atmospheric chemistry on the regional scale.

Figures $1 a$ and $b$ show the aerosol optical depth obtained from the TOMS (Total Ozone Mapping Spectrometer) satellite instrument for 19 and 20 May (Torres et al., 2002). Smoke aerosols, composed mainly of soot particles, are expected to absorb

5 radiation and thus give positive values for aerosol optical depth. Such values $(>0)$ are evident approaching the Phoenix area on 19 May (Fig. 1a) but are less prominent on 20 May (Fig. 1b). The TOMS data resolution is $1.25^{\circ}$ longitude by $1.0^{\circ}$ latitude (a square grid approximately $100 \mathrm{~km}$ by $80 \mathrm{~km}$ ), and the local overpass time for the Phoenix area is around noon daily.

10 The aerosol index values $<1$ that appear frequently in the data files do not necessarily represent smoke aerosols. However, in this particular case, evidence from other measurements made in and around Phoenix supports the assertion that these observations do represent smoke aerosols. The contours with aerosol index $>2.5$ in western and southern Mexico are close to the regions identified as the source of the forest fires 15 in various media reports.

Measurements made on 20 May at the Usery Pass surface site, to the southwest of the Phoenix urban area, will be analyzed together with the measurements made from the G-1 aircraft on 21 May and 22 May over the Phoenix urban air shed for indications of the forest fire plume and its net effect on the atmospheric chemistry of this region. In addition, measurements made by the ADEQ at its Central Phoenix site, also known as the Phoenix Supersite site, will be used to supplement our data and support our conclusions.

\section{Measurements over Phoenix of the North Central Mexico forest fire plume}

The measurements made in Phoenix during May-June of 1998 were part of a field

campaign conducted by the DOE Atmospheric Chemistry Program. Surface-level measurements of $\mathrm{NO}_{x}, \mathrm{NO}, \mathrm{NO}_{2}$, ozone, $\mathrm{CO}$, and several hydrocarbons were made at a surface site at Usury Pass, $30 \mathrm{~km}$ from the center of the Phoenix. Measurements were

Forest fire smoke plume

V. R. Kotamarthi et al.

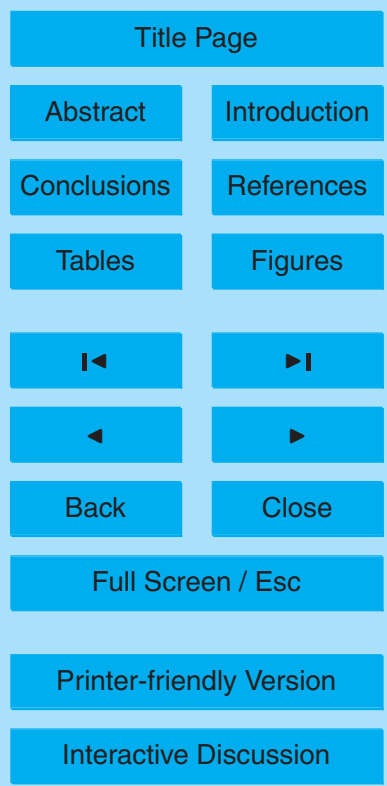


also made from the G-1 aircraft on several of the days. A complete description of the flight plans, mission objectives, and data is online (http://www.Atmos.anl.gov/ACP). The $\mathrm{NO}_{\mathrm{x}}, \mathrm{CO}$, and ozone measurements made at the surface station were reported by Gaffney et al. (2002). The focus here is on two days in May 1998 when aircraft and 5 surface observations of a host of gas-phase chemical tracers were made in and around Phoenix.

20 May was marked by low ozone (30-40 ppbv), high $\mathrm{CH}_{3} \mathrm{Cl}(\sim 900 \mathrm{pptv})$, and low $\mathrm{NO}_{x}$ at the Usery pass site (Gaffney et al., 2002). The Central Phoenix site, located in downtown Phoenix and operated by the ADEQ, also showed remarkable differences on 1020 May versus the other days. Figure $2 a$ shows an average ozone level for a period of approximately four weeks, from 15 May to 12 June, with the diurnal profile for 20 May for comparison. The ozone level for 20 May was less than half of the average value for the corresponding time period during the afternoon peak ozone hours. The diurnal profile on 20 May also showed a flatter, broader peak during the daytime, uncharacteristic of 15 a urban source dominated by locally produced ozone. This observation suggests that the ozone on 20 May originated mostly from long-range transport. This day also had a higher-than-average (by about 50\%) CO level (Fig. 2b), compared to the four-week period defined above. Similar behavior was also shown by the measured PM10 at the Central Phoenix site (Fig. 2c). Interestingly, an appreciable increase in $\mathrm{NO}_{\mathrm{x}}$ was also measured by the ADEQ. This additional $\mathrm{NO}_{\mathrm{x}}$ mostly likely resulted from lower rates of conversion of $\mathrm{NO}_{x}$ to $\mathrm{HNO}_{3}$ in the air as a result of decreased photochemical activity in the smoky conditions. Measurements made away from the city, at the Usery Pass site (Gaffney et al., 2002), show similar low ozone values. The ozone level reported at the Usery Pass site for 20 May ( 40 ppbv) was among the lowest values for the month of May (Fig. 3). The ultraviolet light (UV) recorded on this day was also lower by about $30-50 \%$ than on the previous day (data not shown).

Measurements were also made from the G-1 aircraft on 21 May and 22 May. Unfortunately, no measurements were made from this aircraft platform on 20 May because of poor visibility. However, even on 21 May, the air above the boundary layer was

\section{Forest fire smoke plume}

V. R. Kotamarthi et al.

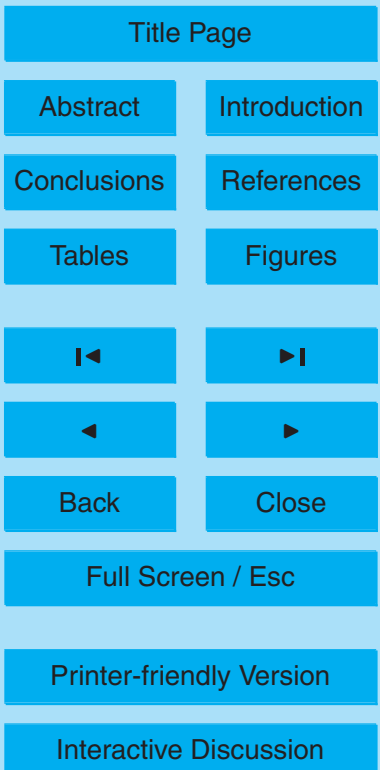


substantially impacted by long-range transport from the forest fires. Figure 4a shows measured ozone from the aircraft platform as a function of altitude and time (GMT). The aircraft climbed from an altitude of $500 \mathrm{~m}$ after takeoff to an altitude of over $3000 \mathrm{~m}$ on both days and then spiraled down to approximately $1000 \mathrm{~m}$. We focus our attention 5 on this level leg of the flight, extending from approximately 60000 seconds GMT (local time 08:20 a.m.) to $62000 \mathrm{~s}$ GMT ( 09:15 a.m.). Measured ozone at approximately the same altitude was lower by almost 20 ppbv on 21 May than on 22 May. The water vapor mixing ratios for these two days differed by a factor of 2-3 (Fig. 4b). The mixing ratios for methyl hydrogen peroxide (Fig. 4c) and hydrogen peroxide (Fig. 4d) were

10 similarly different by factors of 2-3. Lee et al. (1997) reported that biomass burning plumes are generally accompanied by an increase in the mixing ratios of these peroxide compounds. These observations would indicate that the air mass sampled on 21 May from the aircraft platform originated from biomass burning.

In the rest of the discussion, we establish the origin of the air mass by using air15 parcel trajectory calculations, then use model calculations to determine the reasons for the low ozone levels in the plume observed over Phoenix on 20 May 1998.

\section{Model calculations}

Back trajectories from Phoenix were calculated for the month of May 1998 to investigate the origin of the air mass sampled during the field experiment. The calculations were performed mainly to examine the smoke event observed on 20 May over Phoenix. A well-established mesoscale meteorological model (MM5 V.3) was used to generate meteorological fields on fine spatial and time scales for a 20-day period from 10 May to 30 May. The model had a grid resolution of approximately $90 \mathrm{~km}$ by $90 \mathrm{~km}$ and extended from $5^{\circ}$ to $42^{\circ} \mathrm{N}$ latitude and from $130^{\circ}$ to $80^{\circ} \mathrm{W}$ longitude. The 23 vertical levels in the model had vertical resolution ranging from $50 \mathrm{~m}$ near the surface to more than $2 \mathrm{~km}$ at the model top, situated at $100 \mathrm{mb}$. The mesoscale meteorological model was initialized by using NCEP (National Centers for Environmental Protection) 4-D

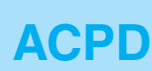

6, 3227-3264, 2006

\section{Forest fire smoke} plume

V. R. Kotamarthi et al.

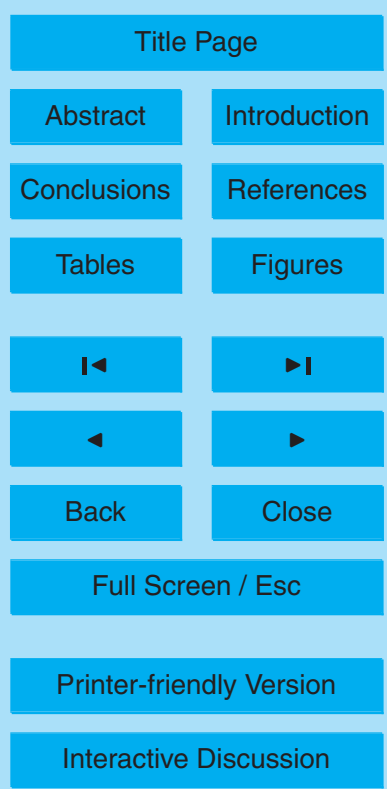


(four-dimensional) reanalysis (version 1) data for May 1998 obtained from the National Center for Atmospheric Research. The NCEP 4-D reanalysis data set was also used to derive the model boundary conditions for the simulation period. Output fields from the model were saved every hour for the 20 days from 10 May to 30 May.

5 Back trajectories based on the calculated wind velocities from the model, usually referred to as kinematic trajectories, were calculated for each day from 15 May to 25 May. The results were then plotted in groups of trajectories, with those originating at $850 \mathrm{mb}$ and below as one set. Mid-troposphere trajectories extending from $850 \mathrm{mb}$ to $500 \mathrm{mb}$ were plotted as the second set, those from $500 \mathrm{mb}$ to $300 \mathrm{mb}$ as the third set.

10 Figure 5 shows the results for air parcels reaching Phoenix on 20 May at approximately 08:00 a.m. The figure shows that for this set of trajectories, the air parcels in the atmospheric boundary layer originated in western Mexico, close to the site of several observed forest fires.

\subsection{Photochemical trajectory calculations}

A nominal trajectory, selected on the basis of the trajectories computed below $850 \mathrm{mb}$, was assigned an initial width of $90 \mathrm{~km}$ (the size of the grid in MM5 simulations). The initial location of the plume was close to the sources of forest fires in western Mexico (Fig. 5). This plume was also assumed to grow as a function of time with a coefficient derived from Gelinas and Walton (1979) and Gifford (1982). Figure 6 shows the selected nominal trajectory as the black line and the outer limits of the plume as it evolves as the green lines surrounding the blue nominal trajectory. The final width of the plume after five days of travel time is approximately $500 \mathrm{~km}$. The plume is thus modeled as an entraining plume, and ambient conditions are set to background conditions from measurements in this region and global-scale three-dimensional chemical-transport model results (MOZART; Wei et al., 2002).

Forest fire smoke plume

V. R. Kotamarthi et al.

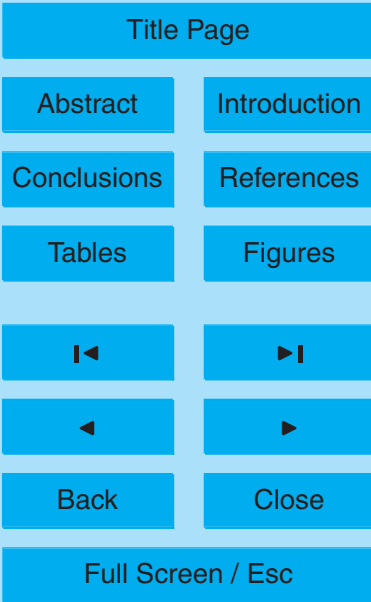

Printer-friendly Version

Interactive Discussion 
No measurements close to the forest fires were available for setting the initial conditions for trace gases in the plume. As s result, we used scaling factors obtained from previous field experiments to set the initial conditions in the plume. An important constraint 5 on this process was obtained from measured concentrations of $\mathrm{CH}_{3} \mathrm{Cl}$, known to be emitted in large quantities during biomass burning events (Andreae et al., 1996), at the Usery Pass surface site during the experimental period. The measurements showed a peak value of 900 pptv on the early morning of 20 May and background mixing ratios on the order of 600 pptv for the rest of the week (Gaffney et al., 2002). We used the value of 900 pptv for $\mathrm{CH}_{3} \mathrm{Cl}$ to estimate the initial $\mathrm{CH}_{3} \mathrm{Cl}$ level in the plume by running the trajectory-photochemical model repeatedly under the given dilution rates. Figure 7 shows the final rate of decrease calculated for $\mathrm{CH}_{3} \mathrm{Cl}$ in the plume and the initial condition, $2.2 \mathrm{ppbv}$, required to reproduce the measured final mixing ratio of $900 \mathrm{pptv}$. For this set of calculations, the background mixing ratio of $\mathrm{CH}_{3} \mathrm{Cl}$ was set to 600 pptv to 15 calculate the entrainment. The $\mathrm{CH}_{3} \mathrm{Cl}$ initial conditions thus obtained were then used to obtain $\mathrm{CO}$ from correlations between $\mathrm{CH}_{3} \mathrm{Cl}$ and $\mathrm{CO}$ reported for measurements near forest fires (Andreae et al., 1996). Using these estimated CO mixing ratios and the reported correlations between $\mathrm{CO}$ and hydrocarbons, we initialized non-methane hydrocarbons (NMHCs) (Hao et al., 1996). A similar procedure was used for initial20 izing $\mathrm{NO}_{\mathrm{x}}$ (Lacaux et al., 1996). Thus, we have a fairly robust estimate of the initial conditions in the trajectory air parcel, giving us confidence in the results based on this model. The initial mixing ratios of some of the key trace gases used in the model are presented in Table 1. The ambient mixing ratios used for various trace gases and entrained into the plume are listed in Table 2. The model was run forward for five 25 days, from the approximate location in western Mexico, to reach Phoenix on 20 May at around 08:00 a.m. During this five-day period, we also periodically updated column ozone based on TOMS data for this time in this region, for use in calculating photolysis rates.

\section{Forest fire smoke} plume

\section{R. Kotamarthi et al.}

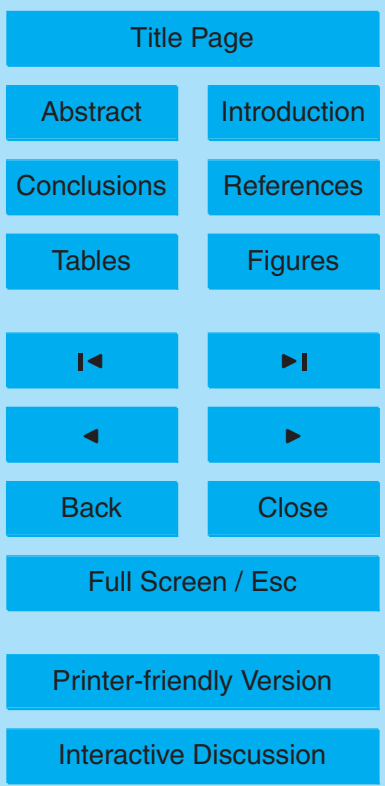


A box photochemical model was used to investigate the formation of ozone and the effect of the smoke plume on the evolution of ozone inside the photochemical trajectory described above. The base version of the model has full representation of $\mathrm{NO}_{\mathrm{x}}$, $5 \mathrm{O}_{\mathrm{x}}, \mathrm{HO}_{\mathrm{x}}, \mathrm{CH}_{4}$, and $\mathrm{CO}$ chemistry, and the reaction rates and photolytic cross section are based on the recommendations of DeMore et al. (1997, and previous versions of "JPL-97"). The NMHC reaction scheme used is based on the RACM (Regional Atmospheric Chemistry Mechanism) mechanism proposed by Stockwell et al. (1997). The prognostic equations for the chemical evolution of the trace gases with time are solved

by using the GEAR package of Hindmarsh (1983). The complete chemical scheme represents 79 different gas species, 214 thermal reactions, and 32 photolysis reactions (Kotamarthi et al., 2001). The photolysis rate calculations are performed by using the FAST-J code of Wild et al. (2000). This photolysis code was designed for calculating photolysis rates mainly in the troposphere and also to calculate the impact of clouds and aerosol layers of various types on calculated photolysis rates. We adopted this photolysis code for our photochemical model (described above) for this set of calculations to account for the presence of smoke aerosols and their effect on photolysis rates.

Black carbon was modeled as absorbing and scattering aerosol. The optical properties of the carbon soot particles were modeled by using a Mie code (Mischenko et al., 1999) to derive the first seven terms of the Legendre polynomial of the scattering function required by the FAST-J code. The smoke aerosol was assumed to have a lognormal distribution with a geometric mean radius of $0.05 \mu \mathrm{m}$ and a standard deviation $\ln \sigma_{g}$ of 0.6 (Wong and $\mathrm{Li}, 2002$ ) and a particle size range of $0.01-10 \mu \mathrm{m}$. The real and 25 imaginary parts of the refractive index were set to 1.56 and 0.025 , respectively (Wong and Li, 2002; Yamasoe et al., 1998). This yields a single scattering albedo of 0.82 , in the range of values reported by Kaufman et al. (1998) for smoke aerosols.

To evaluate the range of impacts of aerosols on photochemical rates, the soot

\section{Forest fire smoke} plume

V. R. Kotamarthi et al.

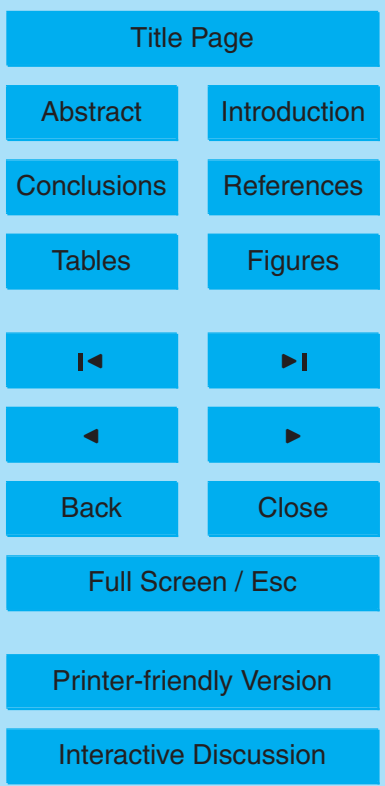


layer was assumed to have logarithmic distribution with height and was held constant throughout the five-day simulation. The aerosol concentration was assumed to be $5000 \mathrm{ng} / \mathrm{m}^{3}$ at the surface, decreasing logarithmically to $1 \mathrm{ng} / \mathrm{m}^{3}$ at an altitude of $10 \mathrm{~km}$ in the model. This implies that no sedimentation of the particle occurs during the five-

5 day travel time, which is incorrect; however, since the focus here is on investigating the bounds of the effect on the plume, we consider this approximation acceptable. Figures $8 \mathrm{a}$ and $\mathrm{b}$ show the calculated reductions in the photolysis rates of ozone and $\mathrm{NO}_{2}$, respectively as a function of solar zenith angle. The percent difference in these two photolysis rates as a result of the smoke layer is shown in Fig. 8c. The aerosol 10 layer affects the $\mathrm{NO}_{2}$ photolysis rates at a much higher rate than it affects the ozone photolysis rate. This would indicate that the aerosols are more absorbing in the range $350-400 \mathrm{~nm}$ (where most of the $\mathrm{NO}_{2}$ photolysis occurs) than in the range below $350 \mathrm{~nm}$ (where most of the ozone photolysis in the troposphere occurs).

\section{Results}

15 A number of model simulations were performed to evaluate the effects of various parameters within and outside the plume on the predicted ozone mixing ratio. The base case calculation employed $\mathrm{NO}_{x}$ at 200 pptv in the ambient air surrounding the plume and entrained into it. The water vapor mixing ratio was set to $1000 \mathrm{ppm}$, corresponding to the low water vapor level observed from the G-1 aircraft (Fig. 4b). The second case used a higher water vapor mixing ratio of $9000 \mathrm{ppm}$ of $\mathrm{H}_{2} \mathrm{O}$, corresponding to the water vapor measured on 21 May from the G-1 (Fig. 4b). A third calculation employed 200 pptv of ambient $\mathrm{NO}_{x}$ and $9000 \mathrm{ppm}$ of $\mathrm{H}_{2} \mathrm{O}$ and included the effect of the smoke aerosol layer on photolysis rates, calculated as discussed in Sect. 3.3. This case is expected to approximate the decrease in UV observed at the Usury Pass site (Gaffney et al., 2001). Figure 9 shows the results from this set of runs for ozone mixing ratios over the five-day period. The first $24 \mathrm{~h}$ are marked by a nearly $75 \%$ increase in ozone for the base case and the case with increased $\mathrm{H}_{2} \mathrm{O}$ mixing ratios. The later development of

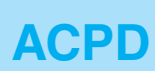

6, 3227-3264, 2006

\section{Forest fire smoke} plume

V. R. Kotamarthi et al.

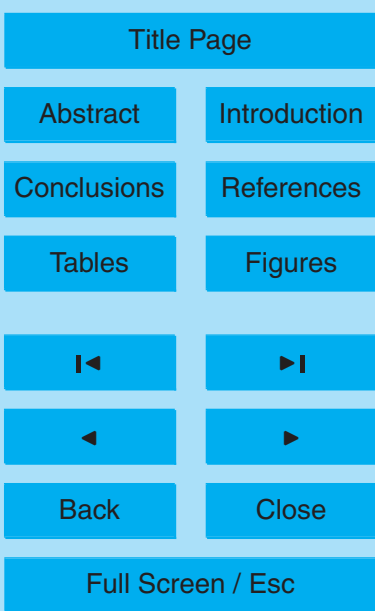

Printer-friendly Version

Interactive Discussion 
ozone in these two plumes is different, however, with the plume with more water vapor containing less ozone (about $15 \mathrm{ppb}$ ) at the end of five days. The decrease in ozone in the case with higher water vapor results from the reaction

$\mathrm{HO}_{2}+\mathrm{O}_{3} \rightarrow 2 \mathrm{H}_{2} \mathrm{O}+\mathrm{O}_{2}$.

5 The loss of ozone increases with the decrease in available $\mathrm{NO}_{\mathrm{x}}$ as the trajectory ages. When a smoke layer was included in the calculations, the water vapor was set to $9000 \mathrm{ppm}$, and the ambient $\mathrm{NO}_{\mathrm{x}}$ was $200 \mathrm{pptv}$, the final ozone obtained was identical to the result for the high-water-vapor case. This is the most likely scenario in this plume. The reduced UV lowers the photochemical activity in the crucial first $24 \mathrm{~h}$ in the

10 life of the plume, reducing the ozone produced in the plume by about $45 \%$ compared to the other two cases shown in Fig. 9. The first three days in the evolution of this smoke-affected photolysis plume closely parallel the case with higher water vapor and $\mathrm{NO}_{\mathrm{x}}$ at 200 pptv. In the case with the smoke layer, the loss of ozone is restricted in the last 1.5 days of plume evolution as a result of higher $\mathrm{NO}_{\mathrm{x}}$ retained (due to lower rates of conversion of $\mathrm{NO}_{x}$ to $\mathrm{HNO}_{3}$ ) and reduced photochemical activity. The final difference in ozone between these two cases is less than $1 \mathrm{ppb}$, whereas the maximum difference between the peak ozone mixing ratios in these two cases is about $15 \mathrm{ppbv}$. Thus, the reduction of the photolysis rate by the smoke layer has the effect of decreasing the peak ozone production in the early evolution of the plume, but the ozone is sustained 20 much longer than in the case with no smoke effect on photolysis rates. In total, the effect of the smoke layer on ozone production in the plume may be minimal over the life of the plume. However, the main reason for the lower ozone losses in the reduced-UV case is the lower $\mathrm{HO}_{2}$, by about $10 \%$ in this case, compared to the no-smoke-layer case; hence, Reaction (R1) is less effective in destroying ozone. The combination of these two factors results in much lower ozone levels than in the other two cases.

Additional sensitivity tests were conducted to evaluate the impact of the ambient $\mathrm{NO}_{\mathrm{x}}$ mixing ratios and the initial conditions of ozone in the plume. The same three cases as above are now repeated with higher ambient $\mathrm{NO}_{\mathrm{x}}$, set to $1.5 \mathrm{ppbv}$ as compared to 200 pptv in the previous simulations. Overall, the behavior of the system remains 3237

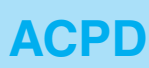

6, 3227-3264, 2006

Forest fire smoke plume

V. R. Kotamarthi et al.

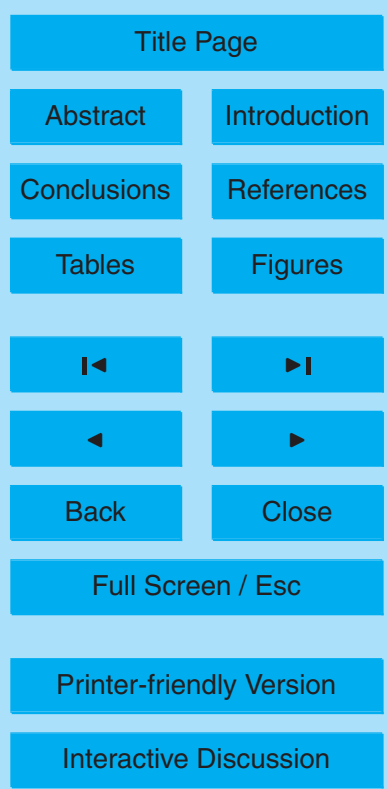


unchanged except for an increase of almost $10 \mathrm{ppb}$ in the final ozone concentration in each of the cases (Fig. 10). Figure 11 shows $\mathrm{NO}_{x}\left(\mathrm{NO}+\mathrm{NO}_{2}\right)$ in the plume as a function of time for cases with ambient $\mathrm{NO}_{\mathrm{x}}$ at $200 \mathrm{pptv}$ and $1.5 \mathrm{ppbv}$. The $\mathrm{NO}_{\mathrm{x}}$ in the plume is nearly threefold higher in case with higher ambient $\mathrm{NO}_{\mathrm{x}}$. Thus, the ambient $\mathrm{NO}_{\mathrm{x}}$ 5 level has the most significant effect on the final ozone concentration in the plume. In our case, with the plume traveling largely over a continental rural background, a mixing ratio of 200 pptv for ambient $\mathrm{NO}_{\mathrm{x}}$ might be more appropriate.

Finally, we tested the sensitivity of the calculated results to the initial ozone mixing ratios in the plume. The results of these calculations (Fig. 12) indicate that the final 10 ozone mixing ratio in the plume is not very sensitive to the initial concentrations, and far less ozone was produced in the plume with high initial ozone than in the plume with low initial ozone. Finally, the increase in $\mathrm{H}_{2} \mathrm{O}_{2}$ in the plume is plotted in Fig. 13. With low water vapor in the plume, the $\mathrm{H}_{2} \mathrm{O}_{2}$ in the plume stays relatively low at $1.25 \mathrm{ppb}$ and remains constant for the period of the simulation. Almost all of the $\mathrm{H}_{2} \mathrm{O}_{2}$ is produced 15 on the first day of simulation for this case. For the case with higher water vapor, $\mathrm{H}_{2} \mathrm{O}_{2}$ increases significantly over the five-day calculation, with smaller increases during the last two days. For the case with a layer of smoke overhead, the final $\mathrm{H}_{2} \mathrm{O}_{2}$ mixing ratio of $3 \mathrm{ppb}$ is in the range of the measurements made from the aircraft platform on 21 May (Fig. 4d).

\section{Conclusions}

We have presented measurements and model calculations for a smoke event in the Phoenix, Arizona, urban area on 20 May and 21 May 1998, that was caused by forest fires in North Central Mexico. The smoke event was marked by low ozone, high water vapor, high $\mathrm{H}_{2} \mathrm{O}_{2}$, and reduced photochemical activity due to the presence of a layer of smoke aerosols. There were also increases in methylchloride and methylhydroperoxides, reported previously as evidence of biomass burning (Lee et al., 1997). Changes in ozone occurred mainly near the source regions (close to the biomass burning), where

Forest fire smoke plume

V. R. Kotamarthi et al.

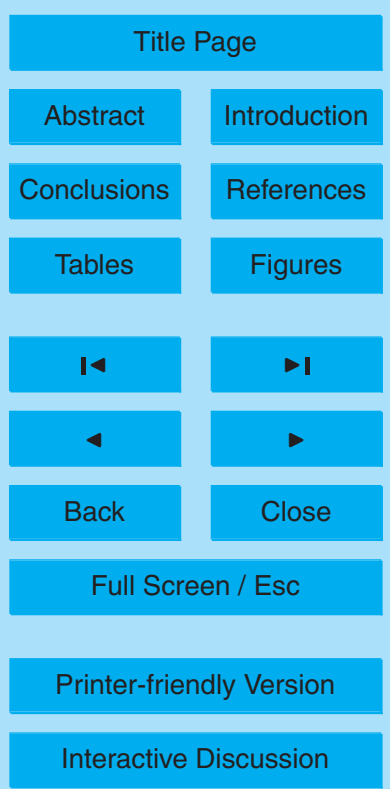


an abundance of hydrocarbons and $\mathrm{NO}_{\mathrm{x}}$ occurred in the plume. The trajectory calculations show that the production of ozone - and, as a consequence, the ozone mixing ratio - in the plume can reach a maximum during approximately the first day of the plume history and that conditions in the plume and overhead can lead to a subsequent 5 decrease of ozone in the plume. The smoke layer of such a plume traveling overhead - but inside the boundary layer - was shown to be capable of decreasing photolysis rates of key tropospheric constituents, such as $\mathrm{NO}_{2}$ and $\mathrm{O}_{3}$, by as much as $20-60 \%$ during the course of a day. The ultimate impact of this reduction in photolytic activity on the evolution of ozone in the plume may, however, be limited.

Acknowledgements. This work was supported by the U.S. Department of Energy, Office of Science, Office of Biological and Environmental Research, Environmental Sciences Division, Atmospheric Chemistry Program, under contract W-31-109-Eng-38. We also wish to thank J. Weinstein-Lloyd for providing the peroxide data set.

\section{References}

Andreae, M. O., Atlas, E., Harris, G. W., Helas, G., de Kock, A., Koppmann, R., Maenhaut, W., Mano, S., Pollock, W. H., Rudolph, J., Scharffe, S., Schebeske, G., and Welling, M.: Methyl halide emissions from savanna fires in southern Africa, J. Geophys. Res., 101, 2360323613, 1996.

DeMore, W. B., Sander, S. P., Golden, D. M., Hampson, R. F., Kurylo, M. J., Howard, C. J., Ravishankara, A. R., Kolb, C. E., and Molina, M. J.: Chemical Kinetics and Photochemical Data for Use in Stratospheric Modeling, Evaluation Number 12, Jet Propulsion Laboratory Publication 97-4, National Aeronautics and Space Administration, Pasadena, CA, 1997.

Doskey, P. V., Rudolph, J., and Kotamarthi, V. R.: Measurements of nonmethane hydrocarbons in Phoenix, Arizona, American Meteorological Society Symposium on Atmospheric Chemistry, Long Beach, CA, AMS Preprints, pp. 30-32, 2000.

Fast, J. D., Doran, J. C., Shaw, W. J., Coulter, R. L., and Martin, T. J.: The evolution of boundary layer and its effect on air chemistry in the Phoenix area, J. Geophys. Res., 105, $22833-$ $22848,2001$.

Forest fire smoke plume

V. R. Kotamarthi et al.

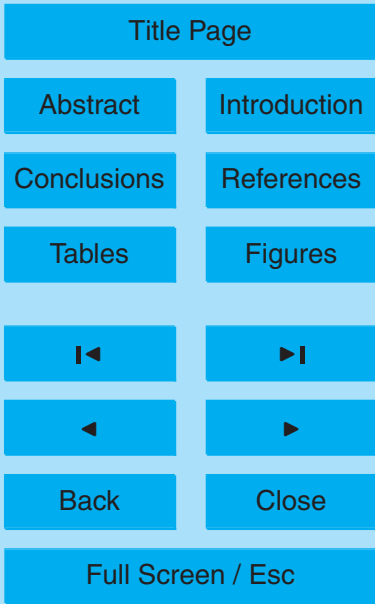

Printer-friendly Version

Interactive Discussion 
Fishman, J., Fakhruzzman, K., Cros, B., and Nganga, D.: Identification of widespread pollution in the Southern Hemisphere deduced from satellite analyses, Science, 252, 1693-1696, 1991.

Gaffney, J. S., Marley, N. A., Drayton, P. J., Doskey, P. V., Kotamarthi, V. R., Cunningham, M. M., Baird, J. C., Dintaman, J., and Hart, H. L.: Field observations of regional and urban impacts of $\mathrm{NO}_{2}$, ozone, UV-B and nitrate radical production rates in the Phoenix air basin, Atmos. Environ., 36, 825-833, 2002.

Gelinas, R. and Walton, J. J.: Dynamic-kinetic evolution of a single plume of interacting species, J. Atmos. Sci., 31, 1807-1813, 1974.

10 Gifford, F. A.: Horizontal diffusion in the atmosphere: A Lagrangian dynamical theory, Atmos. Environ., 16, 505-512, 1982.

Hao, W. M., Ward, D. E., Olbu, G., and Baker, S. P.: Emissions of $\mathrm{CO}_{2}, \mathrm{CO}$, and hydrocarbons from fires in diverse African savanna ecosystems, J. Geophys. Res., 101, 23577-23 584, 1996.

Hindmarsh, A. C.: ODEPACK, A systemized collection of ODE solver, in: Scientific Computing, North-Holland, edited by: Stepleman, R. S., Carver, M., Peskin, R., Ames, W. F., and Vichnevetsky, R., Amsterdam, p. 55-64, 1983.

Kaufman, Y., Hobbs, P. V., Kirchoff, V. W. J. H., Artaxo, P., Remer, L. A., Holben, B. N., King, M. D., Ward, D. E., Prins, E. M., Longo, K. M., Mattos, L. F., Nobre, C. A., Spinhirne, J. D., Ji, Q., Thompson, A. M., Gleason, J. F., Christopher, S. A., and Tsay, S.-C.: Smoke, Clouds, and Radiation-Brazil (SCAR-B) experiment, J. Geophys. Res., 103, 31 783-31 808, 1998.

Kotamarthi, V. R., Gaffney, J. S., Marley, N. A., and Doskey, P. V.: Heterogeneous $\mathrm{NO}_{x}$ chemistry in the polluted PBL, Atmos. Environ., 35, 4489-4498, 2001.

Lacaux, J. P., Delmas, R., Jambert, C., and Kuhlbusch, T. A. J.: NO ${ }_{x}$ emissions from African savanna fires, J. Geophys. Res., 101, 23585-23 595, 1996.

Lee, M., Heikes, B. G., Jacob, D. J., Sachse, G., and Anderson, B.: Hydrogen peroxide, organic hydroperoxide, and formaldehyde as primary pollutants from biomass burning, J. Geophys. Res., 102, 1301-1309, 1997.

Longo, K. M., Thompson, A. M., Kirchoff, V. W. J. H., Remer, L. A., de Freitas, S. R., Silva so Dias, M. A. F., Artaxo, P., Hart, W., Spinhirne, J. D., and Yamasoe, M. A.: Correlation between smoke and tropospheric ozone concentration in Cuiaba during Smoke, Clouds, And Radiation-Barzil (SCAR-B), J. Geophys. Res., 104, 12113-129, 1999.

Mischenko, M. I., Dlugach, J. M., Yanoviyskij, E. G., and Zakharova, N. T.: Bidirectional re-

Forest fire smoke plume

V. R. Kotamarthi et al.

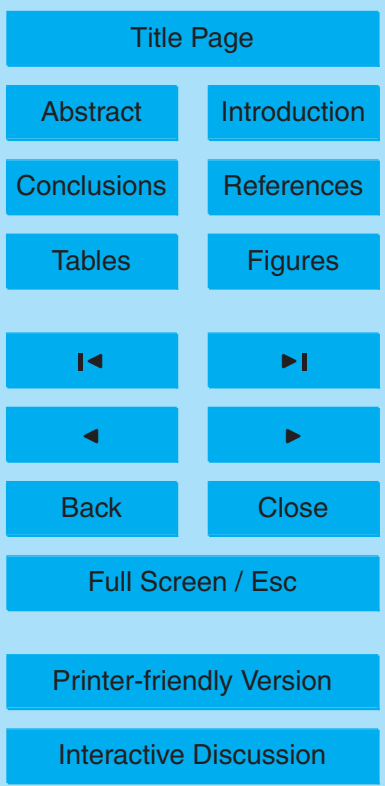

EGU 
flectance of flat, optically thick particulate layers: An efficient radiative transfer solution and applications to snow and soil surfaces, J. Quant. Spectrosc. Radiat. Transfer, 63, 409-432, 1999.

Peppler, R. A., Ashford, L., Bahrmann, C. P., Barnard, J. C., Ferrare, R. A., Halthore, R. A., $5 \quad$ Laulainen, N. S., Ogren, J. A., Poellot, M. R., Sheridan, P., Splitt, M. E., and Turner, D. D.: ARM Southern Great Plains site observations of the smoke pall associated with 1998 Central American fires, Bull. Amer. Meteorol. Soc., 81, 2563-2591, 2000.

Stockwell, W. R., Kirchner, F., and Kuhn, M.: A new mechanism for regional atmospheric chemistry modeling, J. Geophys. Res., 102, 25 847-25879, 1997.

10 Thompson, A. M., Witte, J. C., Hudson, R. D., Guo, H., Herman, J. R., and Fujiwara, M.: Tropical tropospheric ozone and biomass burning, Science, 291, 2128-2132, 2001.

Torres, O., Bhartia, P. K., Herman, J. R., Sinyuk, A., and Holben, B.: A long term record of aerosol optical thickness from TOMS observations and comparison to AERONET measurements, J. Atmos. Sci., 59, 398-413, 2002.

Wei, C. F., Kotamarthi, V. R., Ogunsola, O. J., Horowitz, L. W., Walters, S., Wuebbles, D. J., Avery, M. A., Blake, D. R., Browell, E. V., Sachse, G. W.: Seasonal variability of ozone mixing ratios and budgets in the tropical southern Pacific: A GCTM perspective, J. Geophys. Res., 107, doi:10.1029/2001JD000772, 2002.

Wild, O., Zhu, X., and Prather, M. J.: Fast-J: Accurate simulation of in- and below-cloud photolysis in tropospheric chemical models, J. Atmos. Chem., 37, 245-282, 2000.

Wong, J. and Li, Z.: Retrieval of optical depth for heavy smoke aerosol plumes: Uncertainties and sensitivities to the optical properties, J. Atmos. Sci., 59, 250-261, 2002.

Yamasoe, M. A., Kaufman, Y. J., Dubovik, O., Remer, L. A., Holben, B. N., and Artaxo, P.: Retrieval of the real part of the refractive index of smoke particles from sun-sky measurements during SCAR-B, J. Geophys. Res., 103, 31 893-31 902, 1998.

Forest fire smoke plume

V. R. Kotamarthi et al.

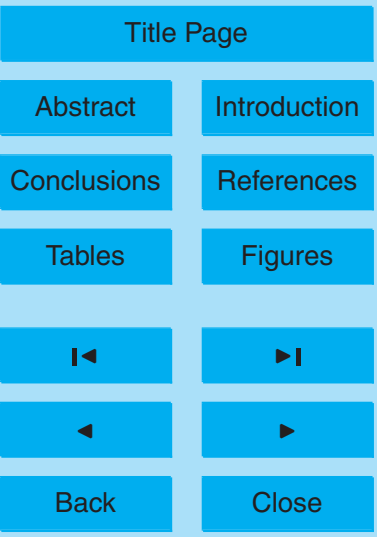

Full Screen / Esc

Printer-friendly Version

Interactive Discussion 


\section{ACPD}

6, 3227-3264, 2006

\section{Forest fire smoke} plume

V. R. Kotamarthi et al.

Table 1. Initial conditions in the plume.

\begin{tabular}{ll}
\hline Trace Gas & Initial Condition \\
\hline Ozone & $40 \mathrm{ppbv}$ \\
$\mathrm{NO}_{\mathrm{x}}$ & $2.5 \mathrm{ppbv}$ \\
$\mathrm{CO}$ & $500 \mathrm{ppbv}$ \\
Ethane & $3.7 \mathrm{ppbv}$ \\
Propane & $950 \mathrm{pptv}$ \\
Ethene & $11.5 \mathrm{ppbv}$ \\
Propene + 1-Butene + 1-Pentene + 1-Hexene & $4.6 \mathrm{ppbv}$ \\
Toluene & $1.5 \mathrm{ppbv}$ \\
\hline
\end{tabular}

Title Page

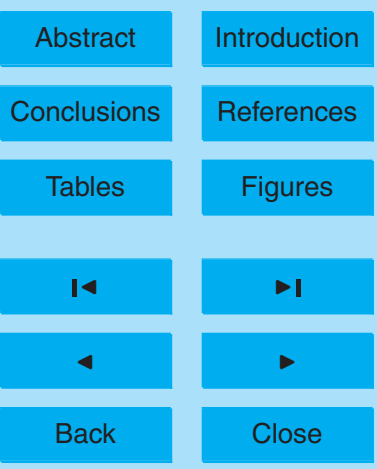

Full Screen / Esc

Printer-friendly Version

Interactive Discussion 


\section{ACPD}

6, 3227-3264, 2006

\section{Forest fire smoke} plume

V. R. Kotamarthi et al.

Table 2. Ambient mixing ratios entrained into the plume.

\begin{tabular}{ll}
\hline Trace Gas & Mixing ratio \\
\hline Ozone & $30 \mathrm{ppbv}$ \\
$\mathrm{NO}_{\mathrm{x}}$ & $200 \mathrm{pptv}$ \\
$\mathrm{CO}$ & $150 \mathrm{ppbv}$ \\
Ethane & $800 \mathrm{pptv}$ \\
Ethene & $25 \mathrm{pptv}$ \\
Propane & $25 \mathrm{pptv}$ \\
Propene + 1-Butene + 1-Pentene + 1-Hexene & $35 \mathrm{pptv}$ \\
\hline
\end{tabular}

\section{Title Page}

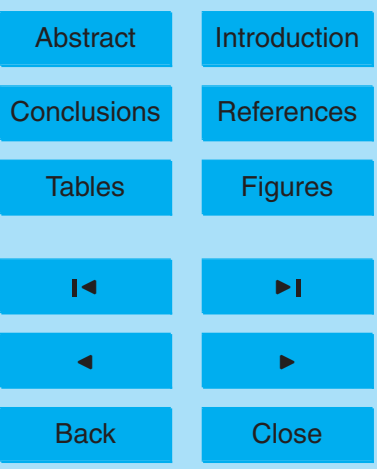

Full Screen / Esc

Printer-friendly Version

Interactive Discussion 


\section{ACPD}

6, 3227-3264, 2006

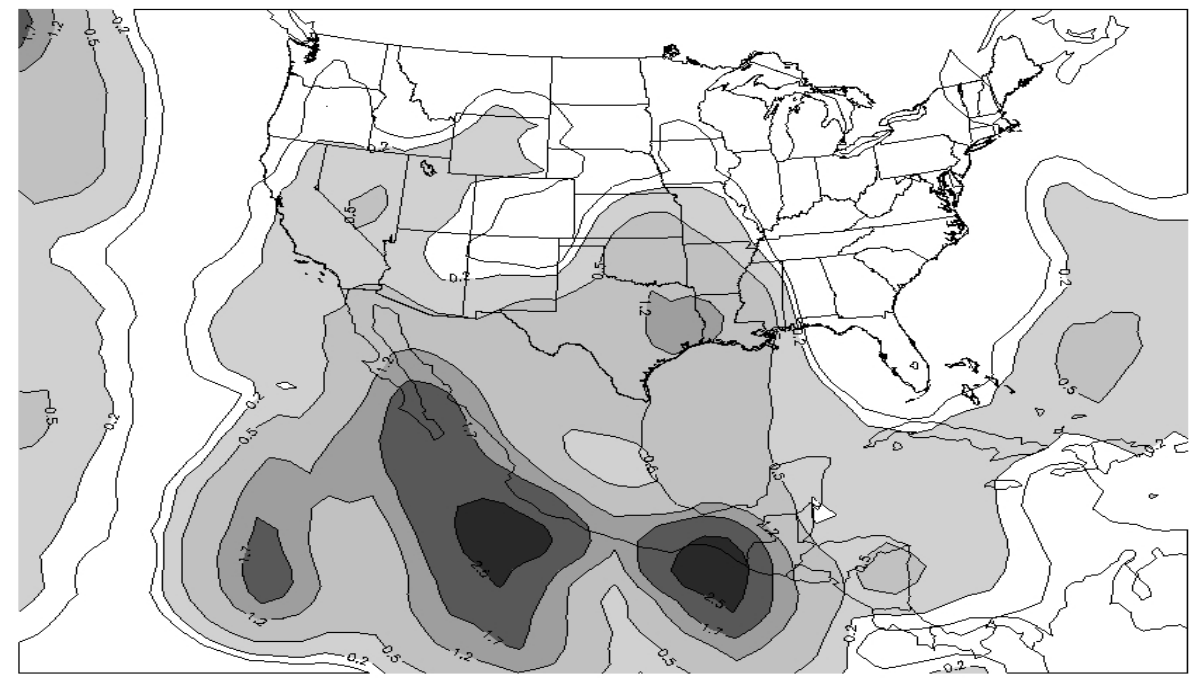

\section{Forest fire smoke plume}

V. R. Kotamarthi et al.

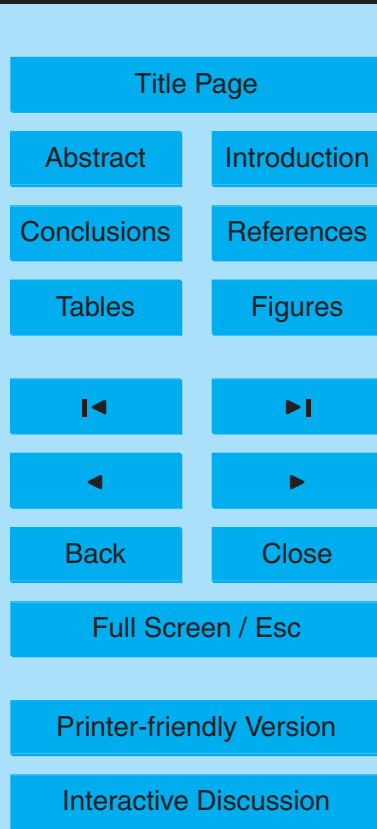

Fig. 1. (a) Aerosol optical depths from the TOMS data set for 19 May. Contours are drawn at $0.1,0.2,0.5,1.2,1.7$, and 2.5 , as labeled. 


\section{ACPD}

6, 3227-3264, 2006

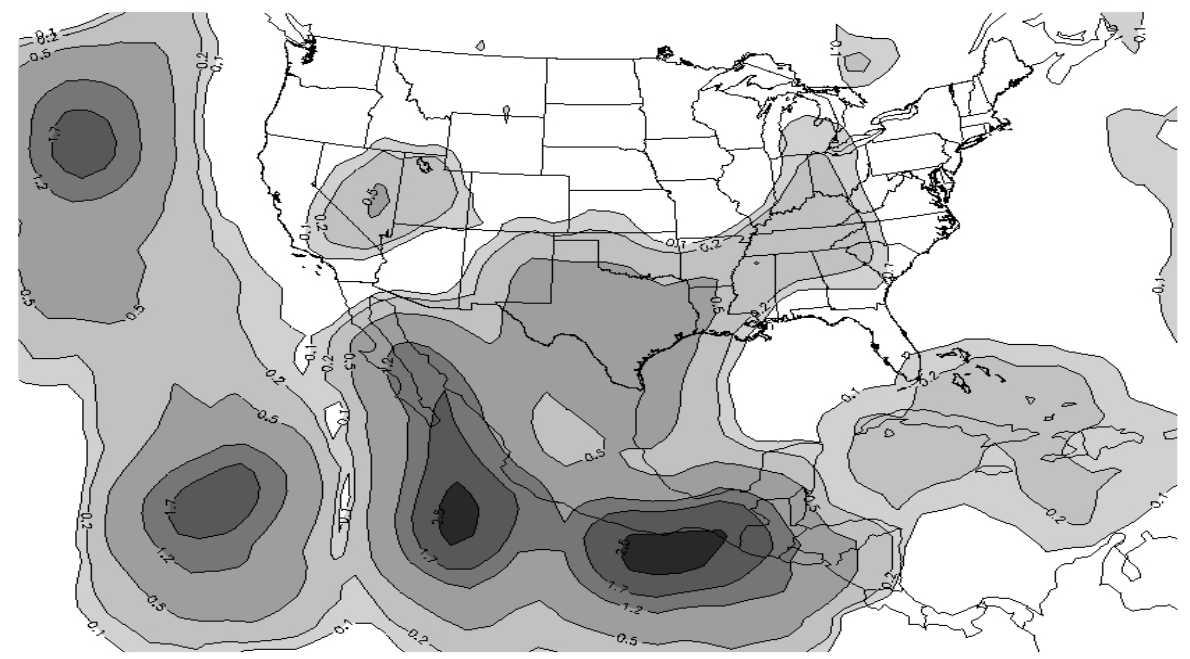

Forest fire smoke plume

V. R. Kotamarthi et al.

Title Page

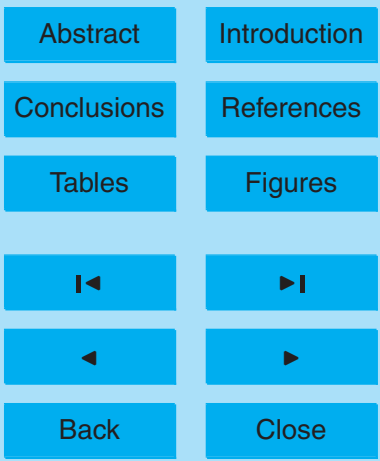

Full Screen / Esc

Fig. 1. (b) Aerosol optical depths from the TOMS data set for 20 May. Contours are drawn at $0.1,0.2,0.5,1.2,1.7$, and 2.5 , as labeled. 


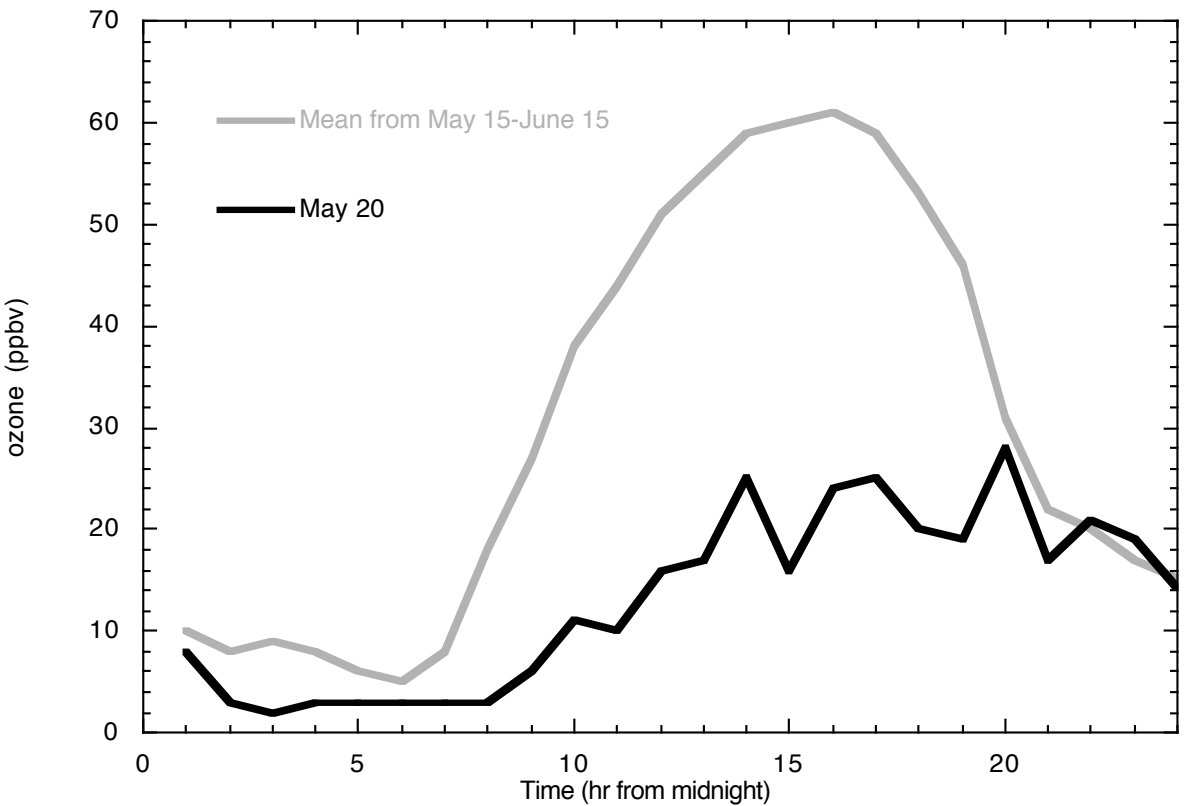

Fig. 2. (a) Diurnal variation of ozone in central Phoenix. The grey line is an average for 15 May to 15 June of 1998 . The black line shows the ozone mixing ratios for 20 May.
ACPD

6, 3227-3264, 2006

\section{Forest fire smoke plume}

V. R. Kotamarthi et al.

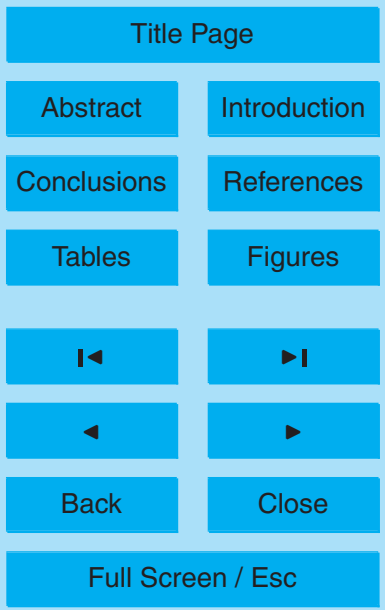

Printer-friendly Version

Interactive Discussion 


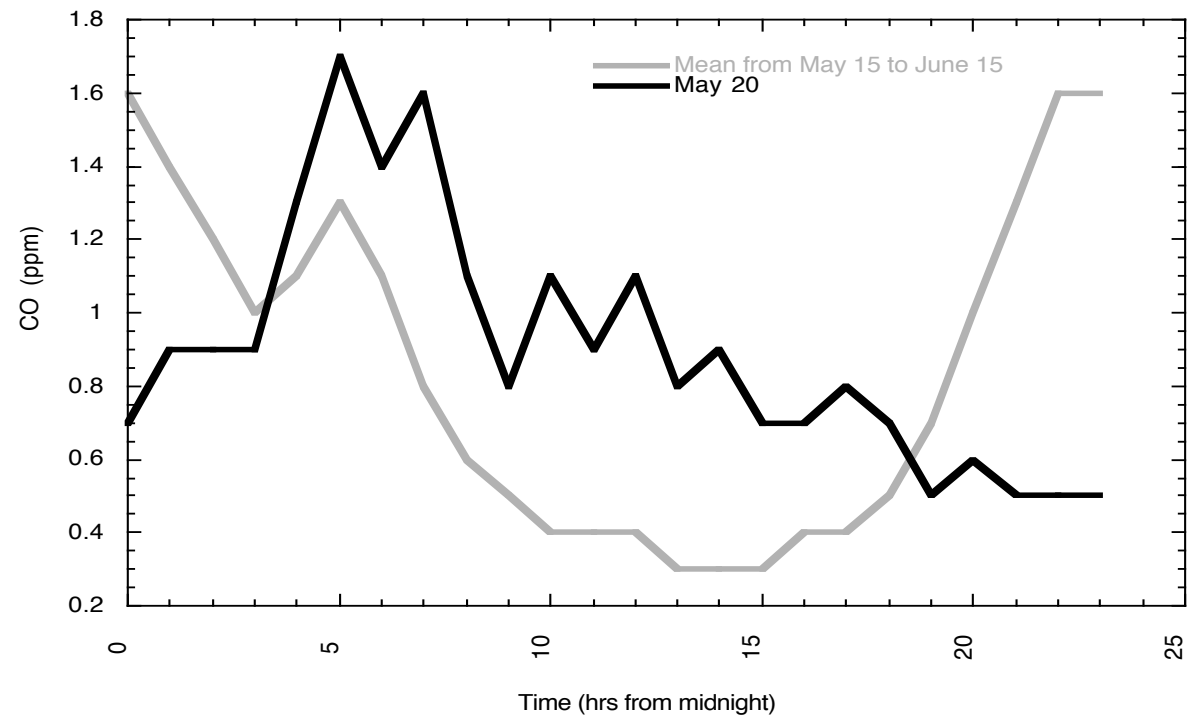

Fig. 2. (b) Diurnal variation of $C O$ in central Phoenix. The grey line is an average for 15 May to 15 June of 1998 . The black line shows the ozone mixing ratios for 20 May.

\section{ACPD}

6, 3227-3264, 2006

\section{Forest fire smoke plume}

V. R. Kotamarthi et al.

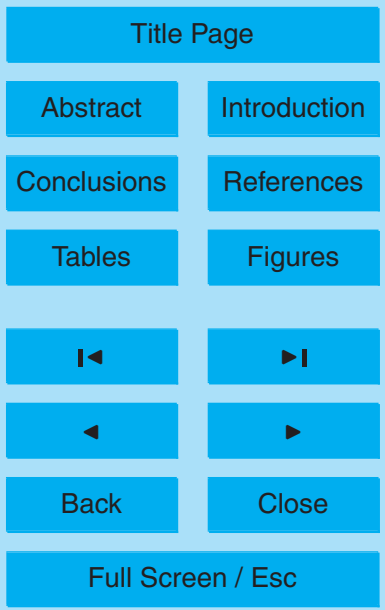

Printer-friendly Version

Interactive Discussion 


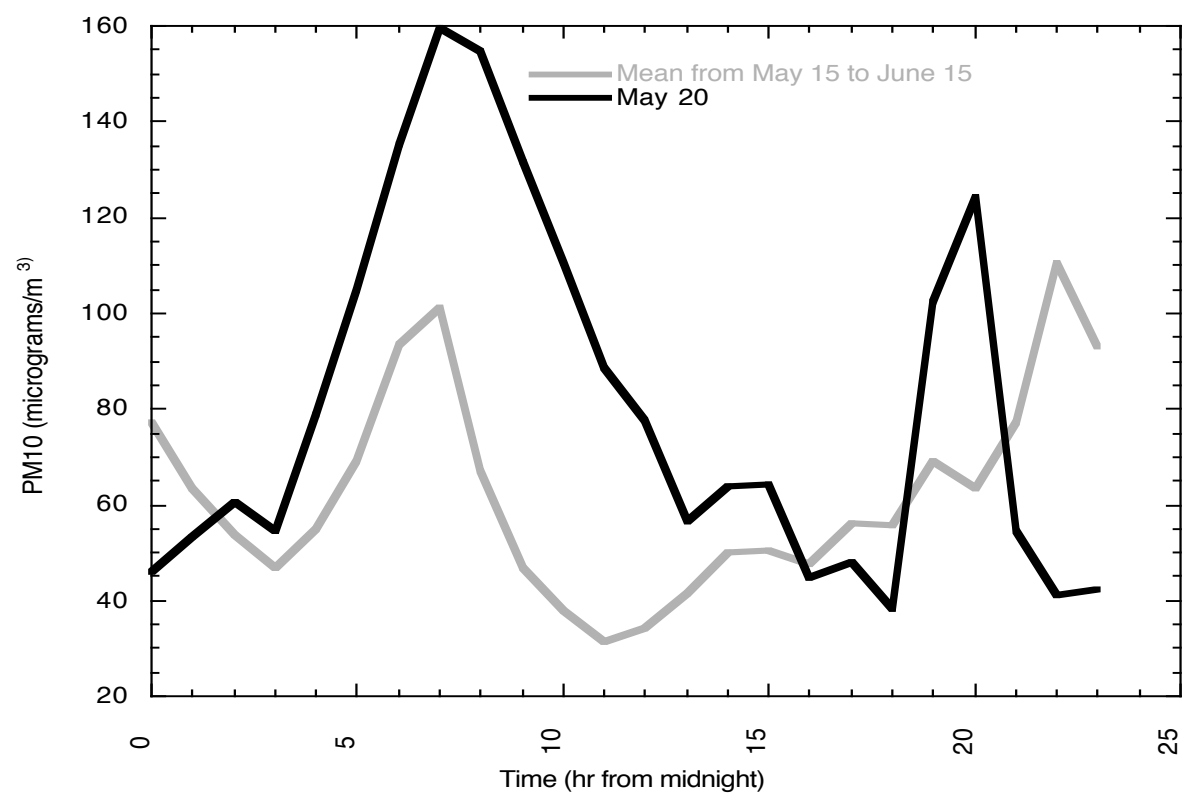

Fig. 2. (c) Diurnal variation of PM10 in central Phoenix. The grey line is an average for 15 May to 15 June of 1998 . The black line shows the ozone mixing ratios for 20 May.

\section{6, 3227-3264, 2006}

\section{Forest fire smoke plume}

V. R. Kotamarthi et al.

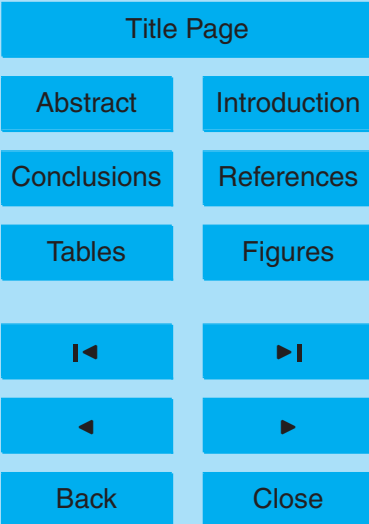

Full Screen / Esc

Printer-friendly Version

Interactive Discussion 


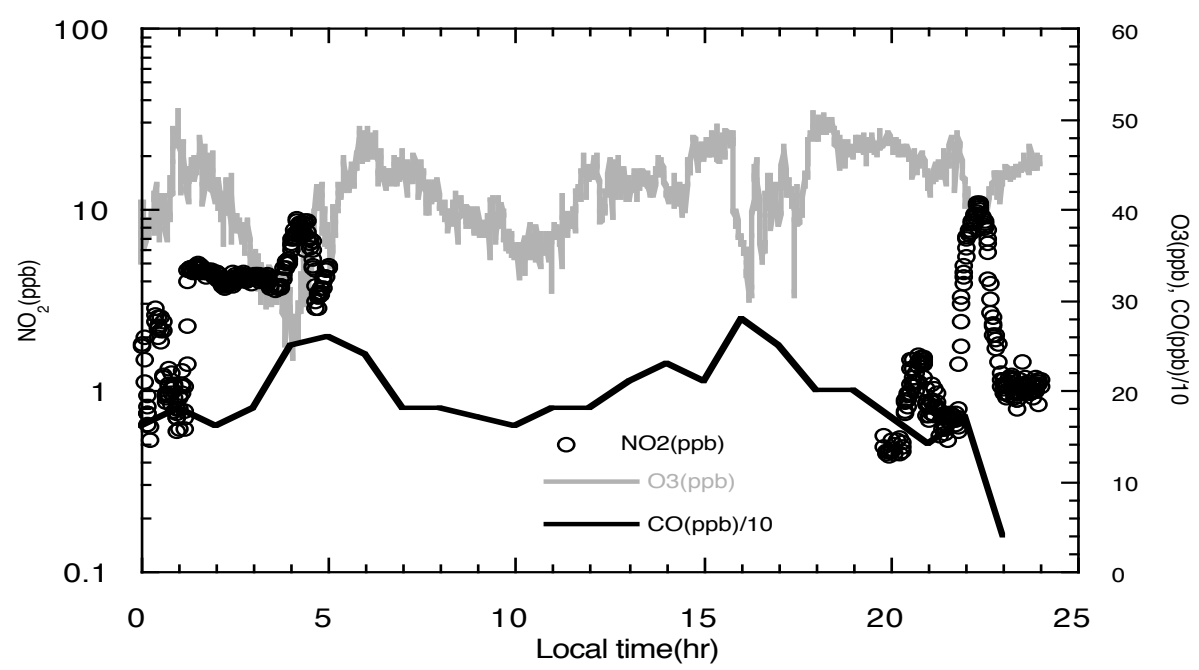

Fig. 3. Measured ozone, $\mathrm{CO}$, and $\mathrm{NO}_{2}$ on the day the smoke plume was observed in Phoenix from the Usery Pass surface site.

\section{ACPD}

6, 3227-3264, 2006

\section{Forest fire smoke plume}

\section{R. Kotamarthi et al.}

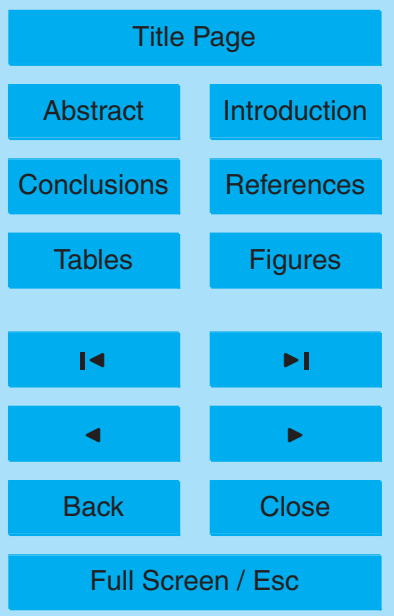

Printer-friendly Version

Interactive Discussion 


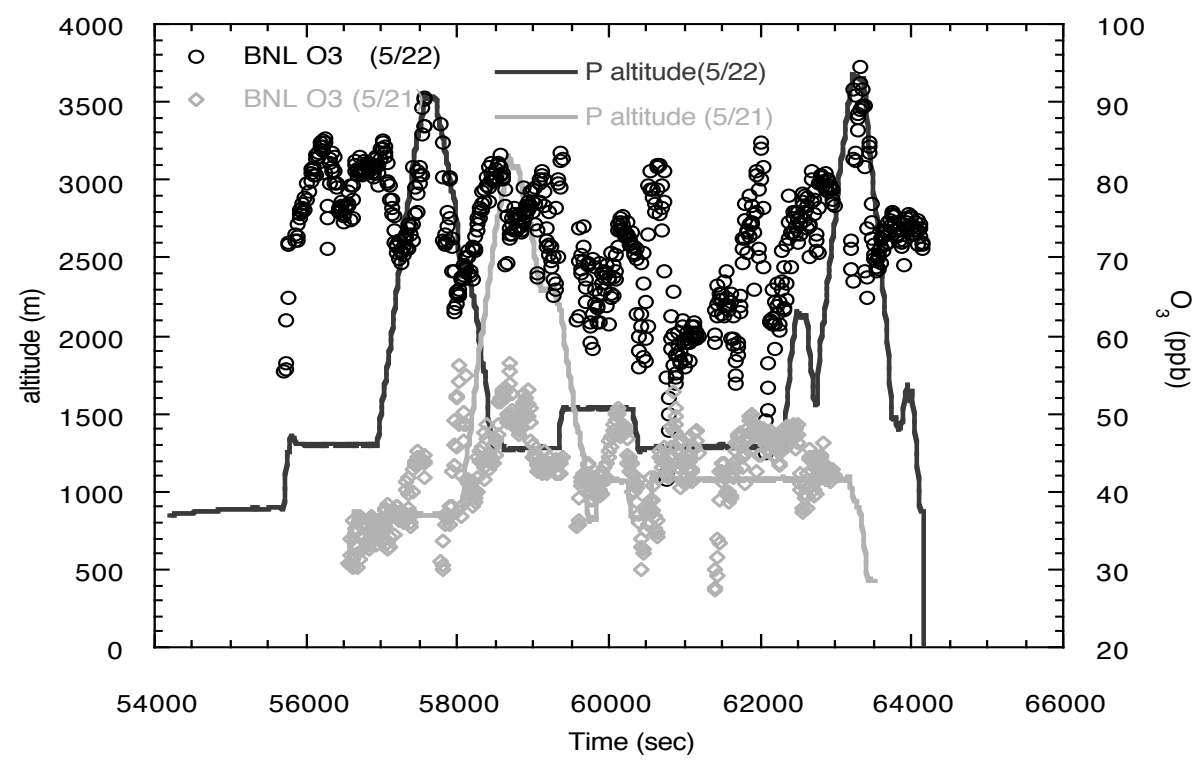

Fig. 4. (a) Measurements made from the G-1 aircraft platform of 21 May (black line and circles) and 22 May (gray line and triangles). The solid lines show the altitude excursion of the plane (left-hand y-axis), and the circles and triangles show the corresponding measured ozone value (right-hand y-axis).

\section{ACPD}

6, 3227-3264, 2006

\section{Forest fire smoke plume}

V. R. Kotamarthi et al.

Title Page

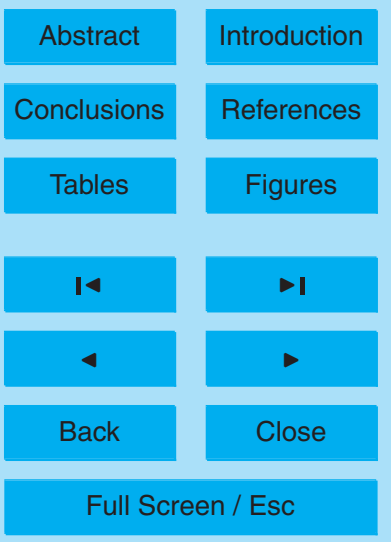

Printer-friendly Version

Interactive Discussion 


\section{ACPD}

6, 3227-3264, 2006

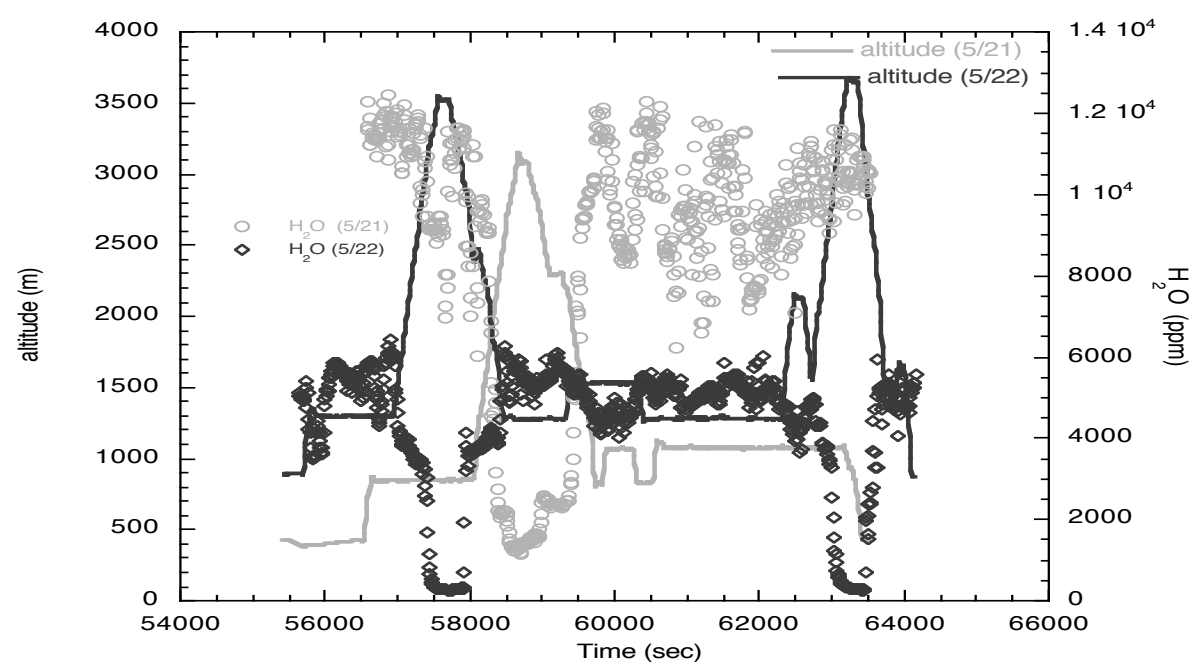

Fig. 4. (b) Lines and symbols correspond to those in Fig. 4a. Here the symbols represent water vapor mixing ratios (right-hand y-axis).

\section{Forest fire smoke plume}

\section{R. Kotamarthi et al.}

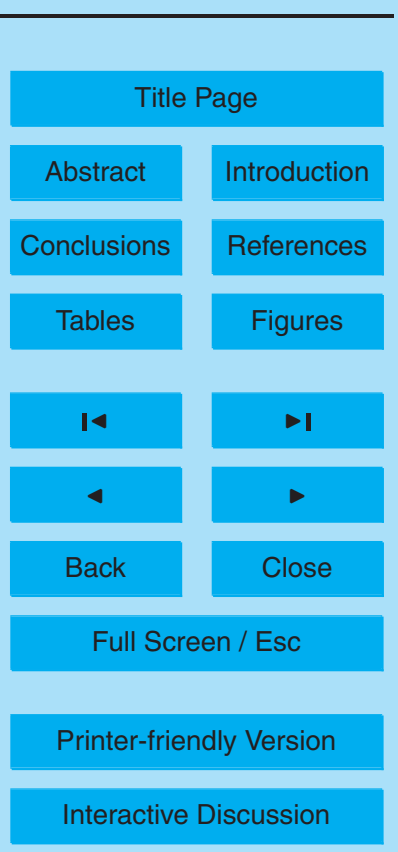




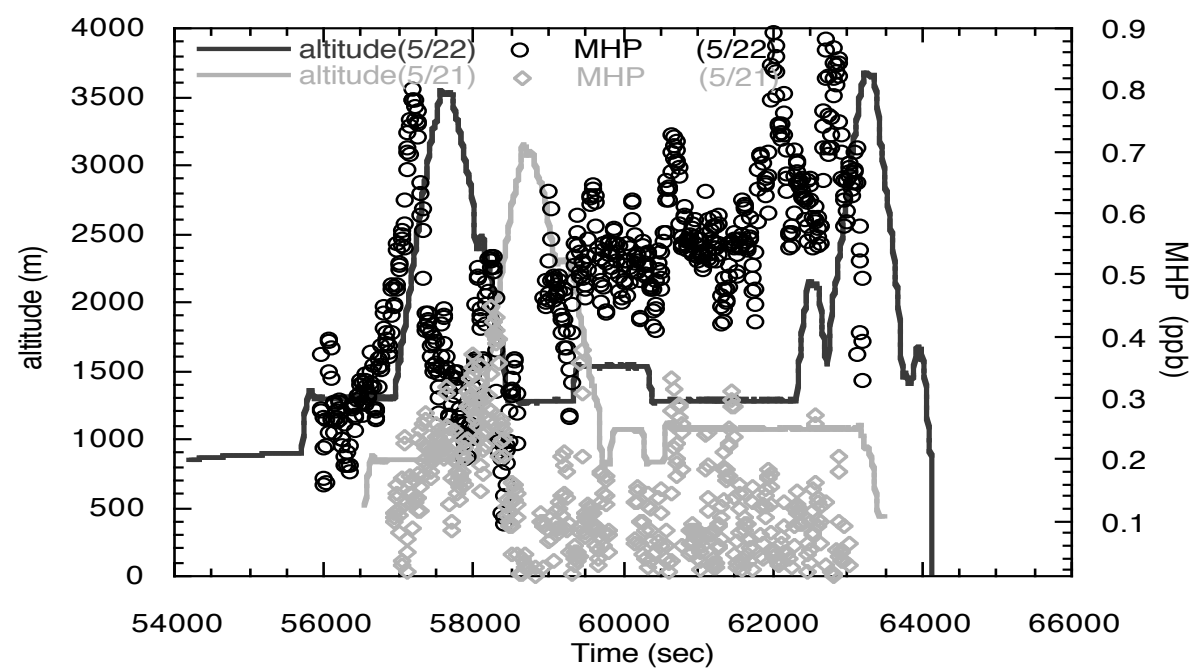

Fig. 4. (c) Lines and symbols correspond to those in Fig. 4a. Here the symbols represent methyl hydrogen peroxide (MHP) mixing ratios (right-hand y-axis).
6, 3227-3264, 2006

\section{Forest fire smoke} plume

\section{R. Kotamarthi et al.}

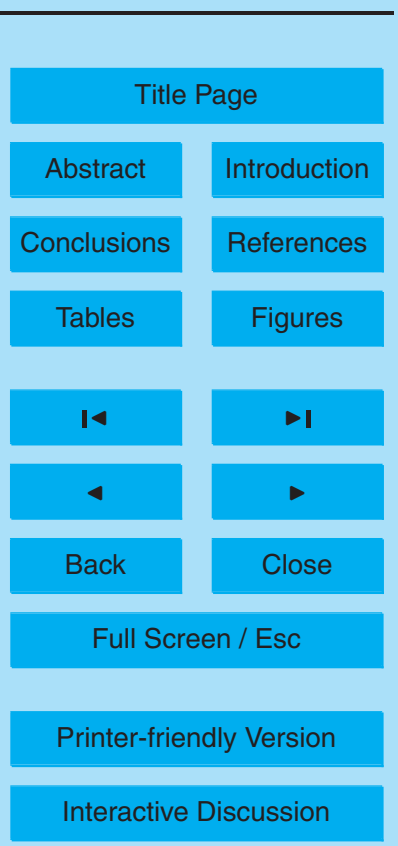




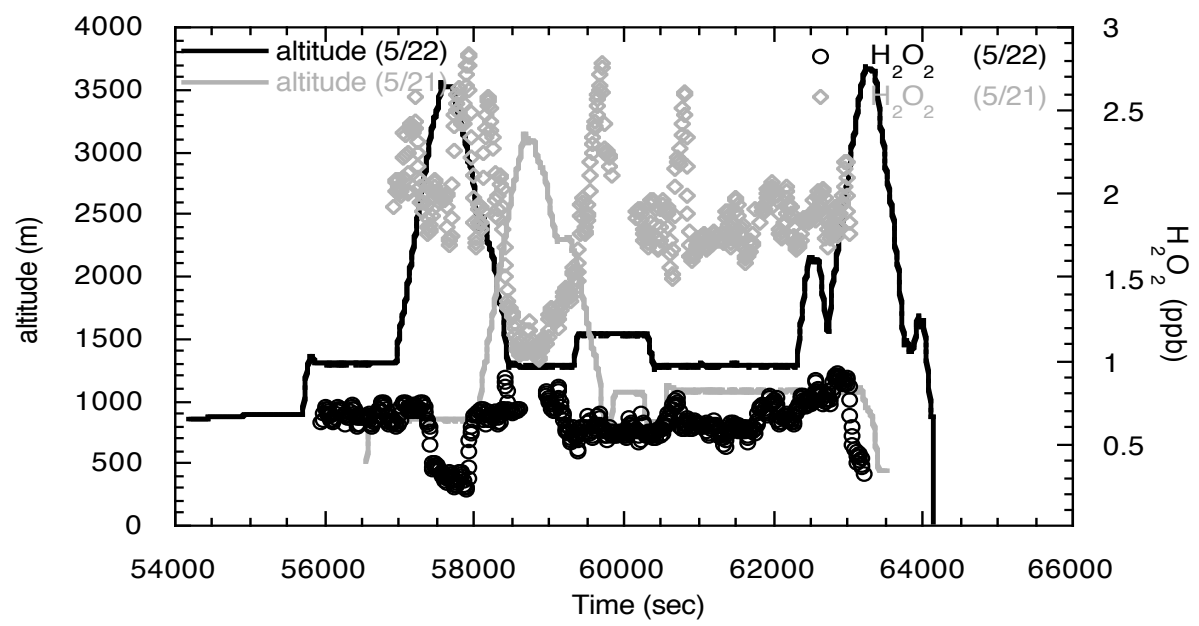

Fig. 4. (d) Lines and symbols correspond to those in Fig. 4a. Here the symbols represent hydrogen peroxide $\left(\mathrm{H}_{2} \mathrm{O}_{2}\right)$ mixing ratios (right-hand y-axis).

\section{ACPD}

6, 3227-3264, 2006

\section{Forest fire smoke plume}

V. R. Kotamarthi et al.

Title Page

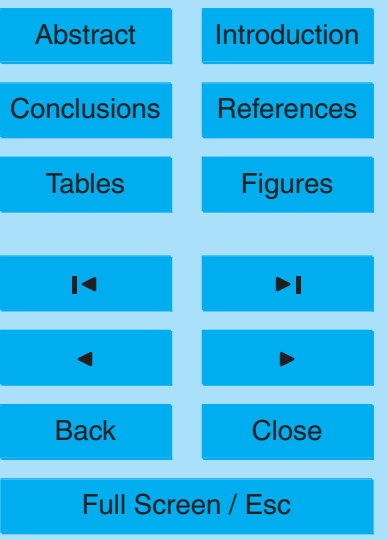

Printer-friendly Version

Interactive Discussion 


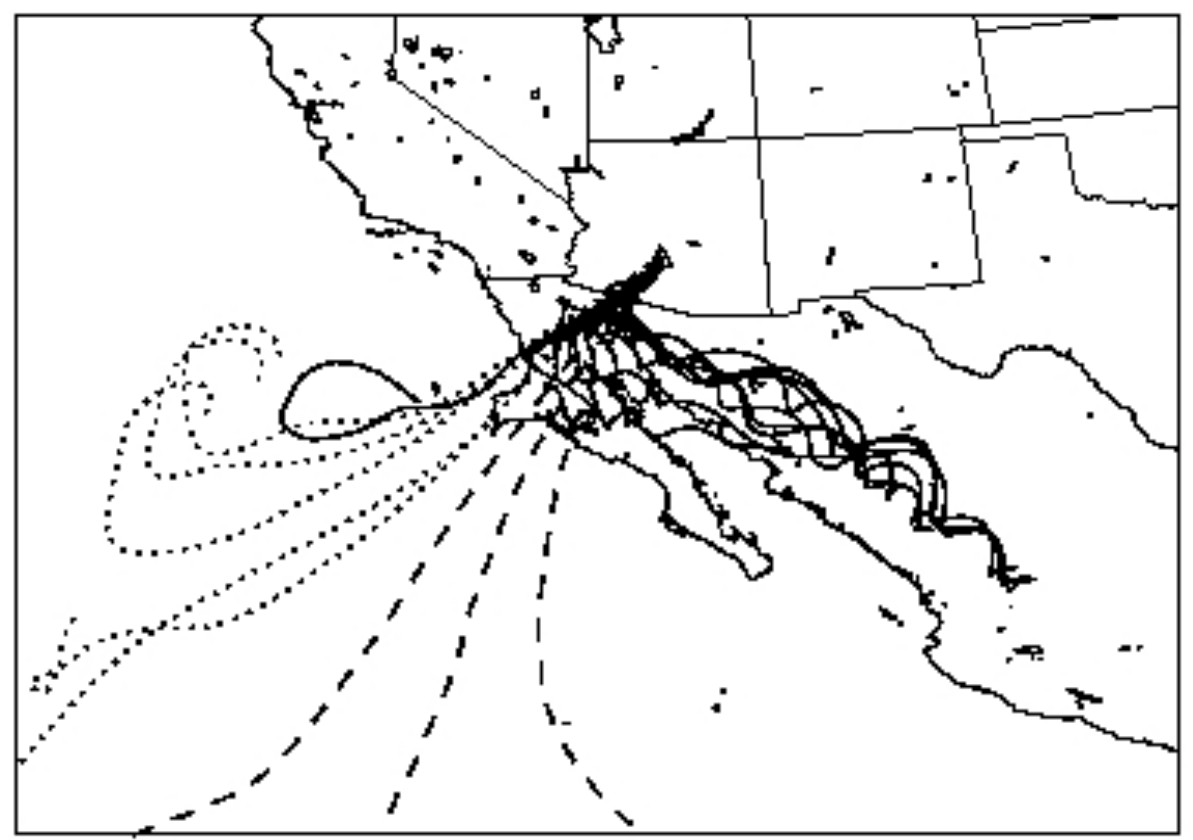

Fig. 5. Plot of backward trajectories to Phoenix for 20 May. Solid lines indicate planetary boundary layer air below $800 \mathrm{mb}$, dashed lines indicates air between 800 and $500 \mathrm{mb}$ air and dotted line indicates air between 500 and $300 \mathrm{mb}$. The backward trajectories from Phoenix were calculated from MM5 (V3) model-generated output on a $90-\mathrm{km}$ by $90-\mathrm{km}$ grid. The output from the model was saved every hour for calculation of these kinematic trajectories.

\section{6, 3227-3264, 2006}

\section{Forest fire smoke plume}

\section{R. Kotamarthi et al.}

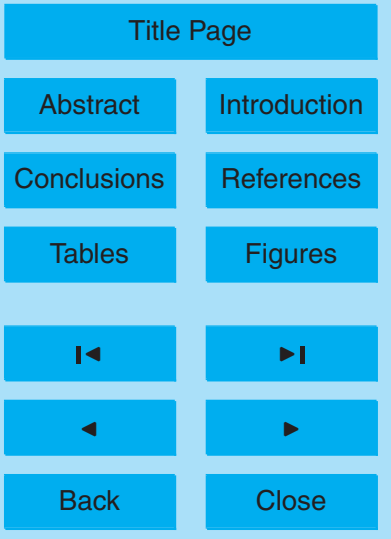

Full Screen / Esc

Printer-friendly Version

Interactive Discussion 


\section{ACPD}

6, 3227-3264, 2006

Backwards from $05 / 20 / 15$ to $05 / 15 / 15$ in the ABL

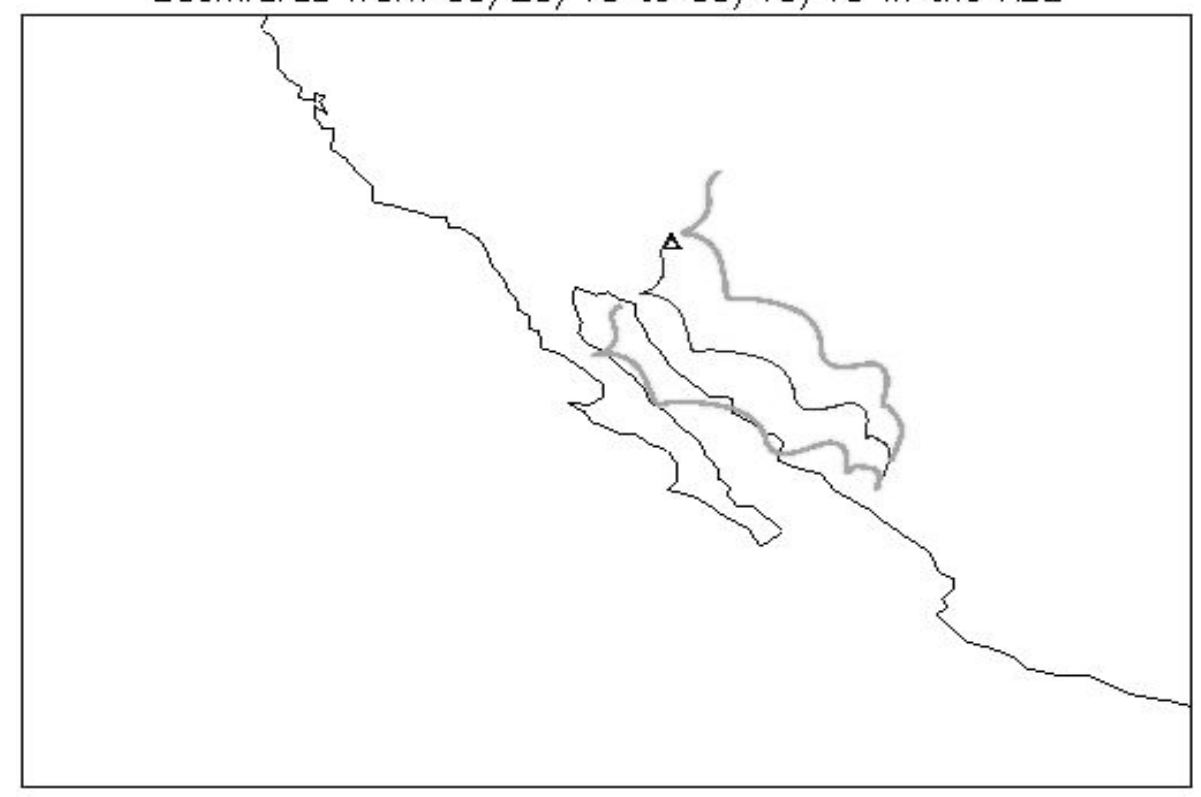

\section{Forest fire smoke plume}

V. R. Kotamarthi et al.

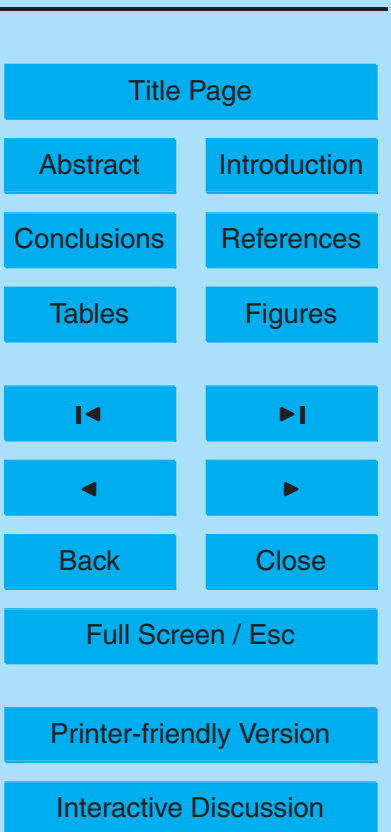

Fig. 6. The spread of the plume as calculated by the model. The black line is the nominal trajectory chosen for the calculations, and the grey lines represent the outer limits of the plume due to dilution. The initial width of the plume was set to $90 \mathrm{~km}$ (the grid size of the MM5 [V3] 


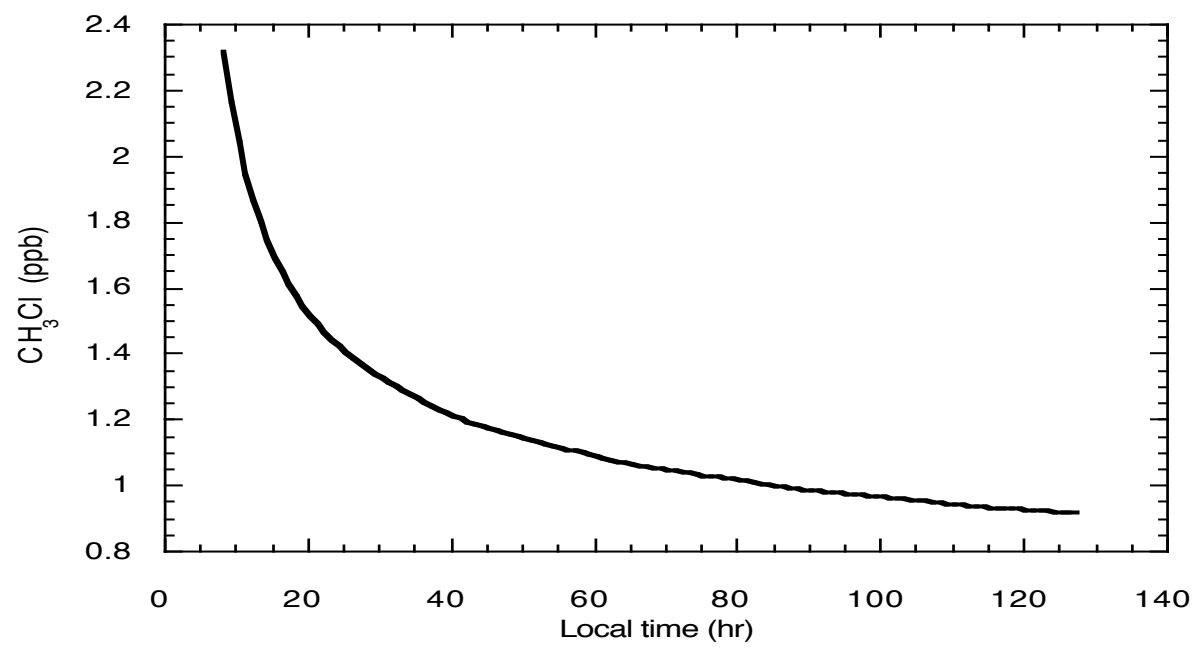

ACPD

6, 3227-3264, 2006

\section{Forest fire smoke} plume

V. R. Kotamarthi et al.

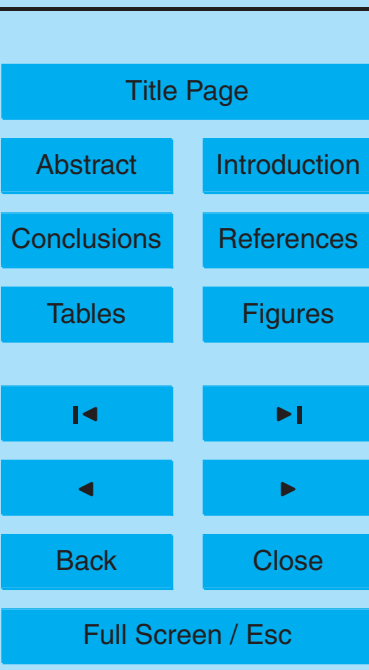

Printer-friendly Version

Interactive Discussion

Fig. 7. Initial conditions of $\mathrm{CH}_{3} \mathrm{Cl}$ in the plume needed to achieve the measured $\mathrm{CH}_{3} \mathrm{Cl}$ mixing ratio of 900 pptv after five days of plume travel and dilution. 


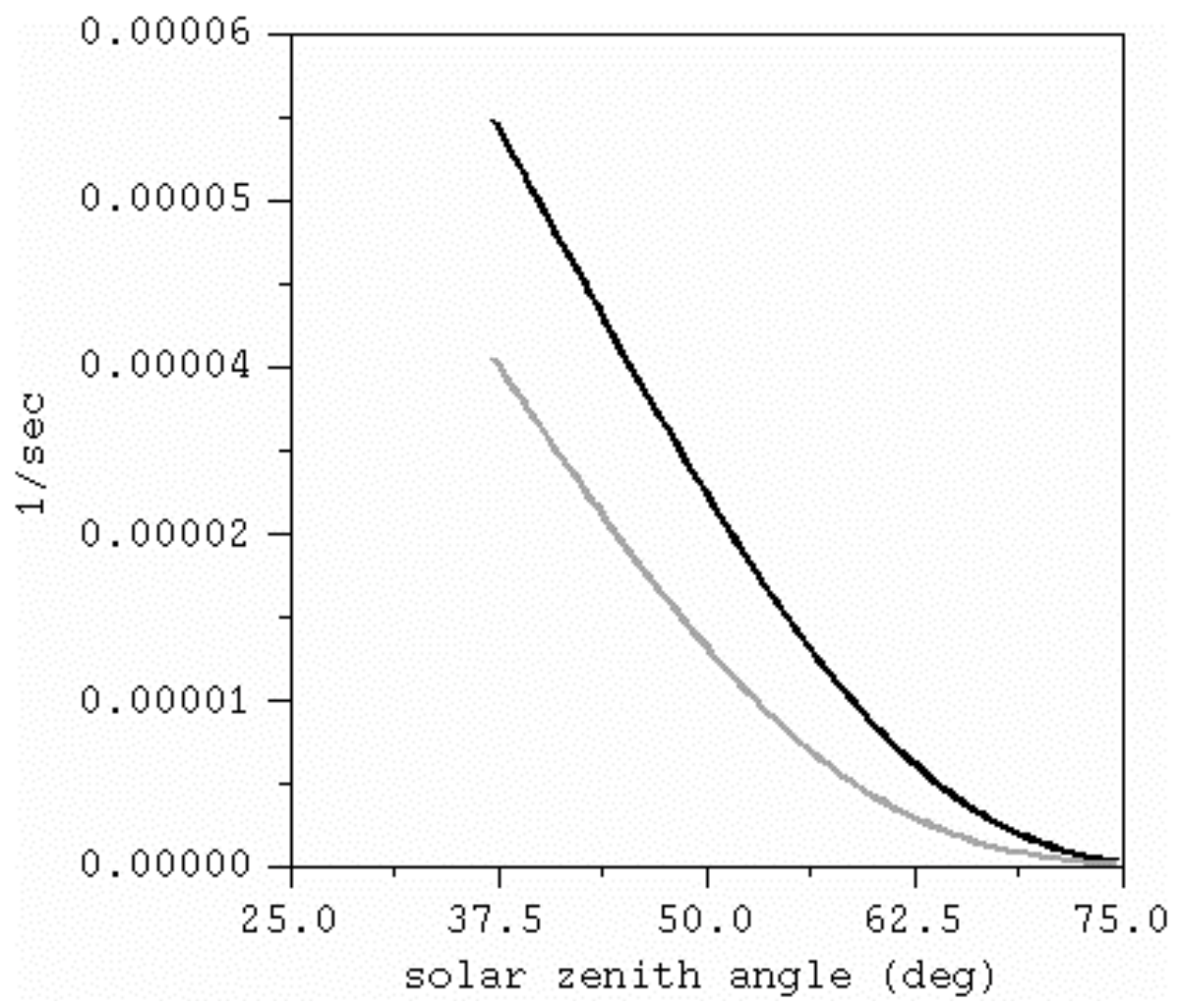

Fig. 8. (a) Calculated photolysis rates for the reaction $\mathrm{O}_{3} \rightarrow \mathrm{O}(1 \mathrm{D})$ as a function of solar zenith angle, with a smoke layer (gray line) and without a smoke layer (black line) for solar and column ozone conditions corresponding to 20 May over Phoenix.

\section{6, 3227-3264, 2006}

\section{Forest fire smoke plume}

\section{R. Kotamarthi et al.}

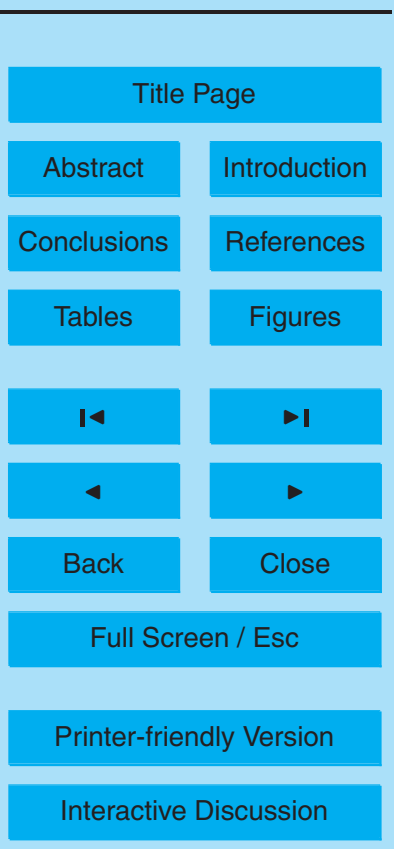




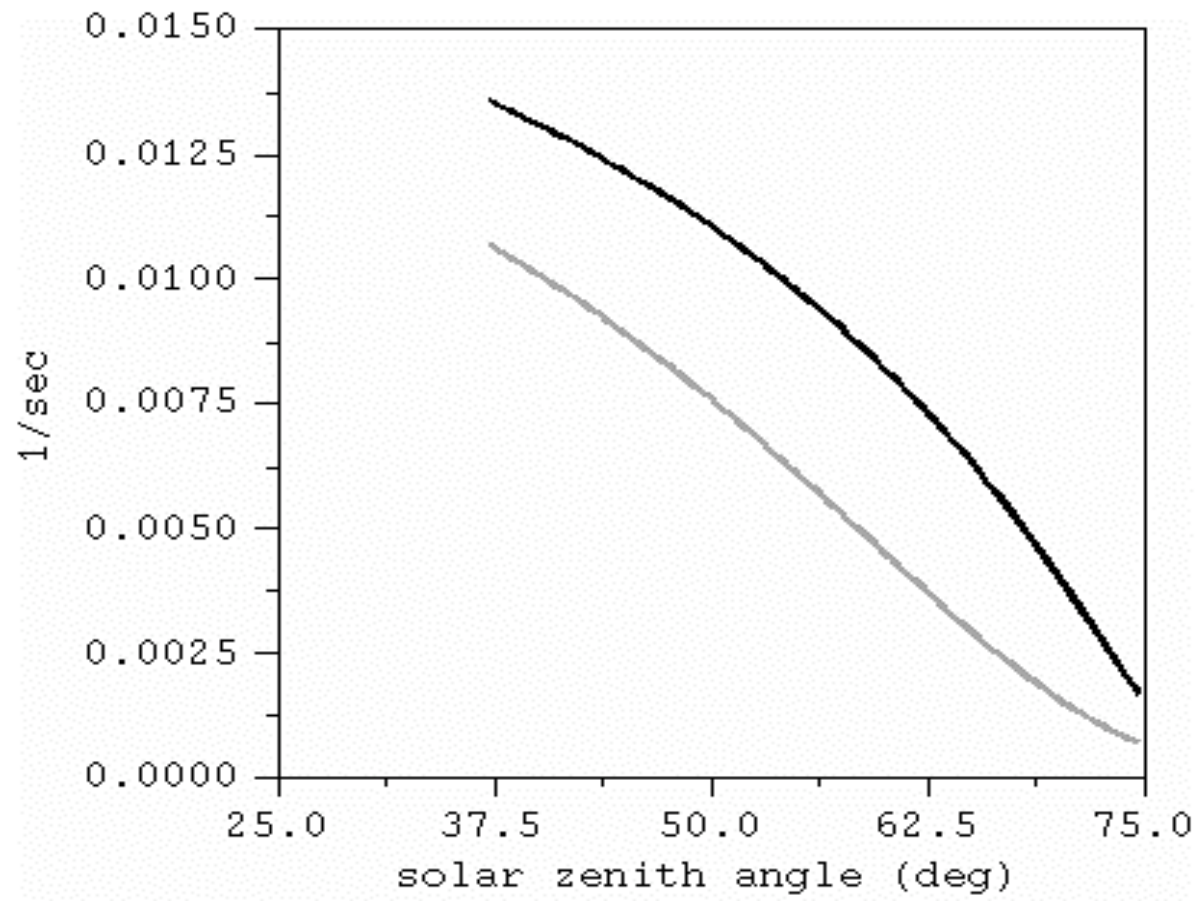

Fig. 8. (b) Calculated $\mathrm{NO}_{2}$ photolysis rates as a function of solar zenith angle, with a smoke layer (gray line) and without a smoke layer (black line), for solar and column ozone conditions corresponding to 20 May over Phoenix.

\section{ACPD}

6, 3227-3264, 2006

\section{Forest fire smoke plume}

\section{R. Kotamarthi et al.}

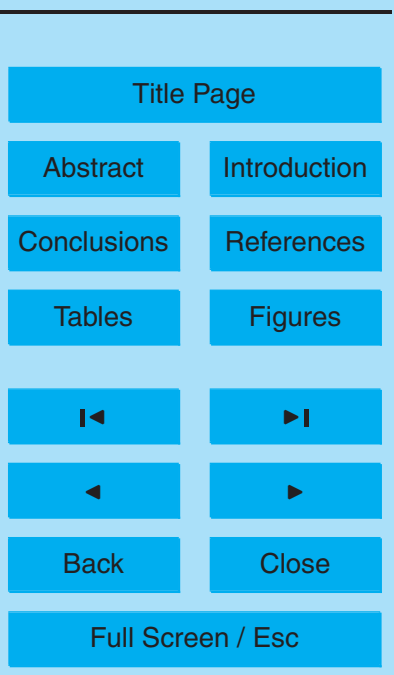

Printer-friendly Version

Interactive Discussion 


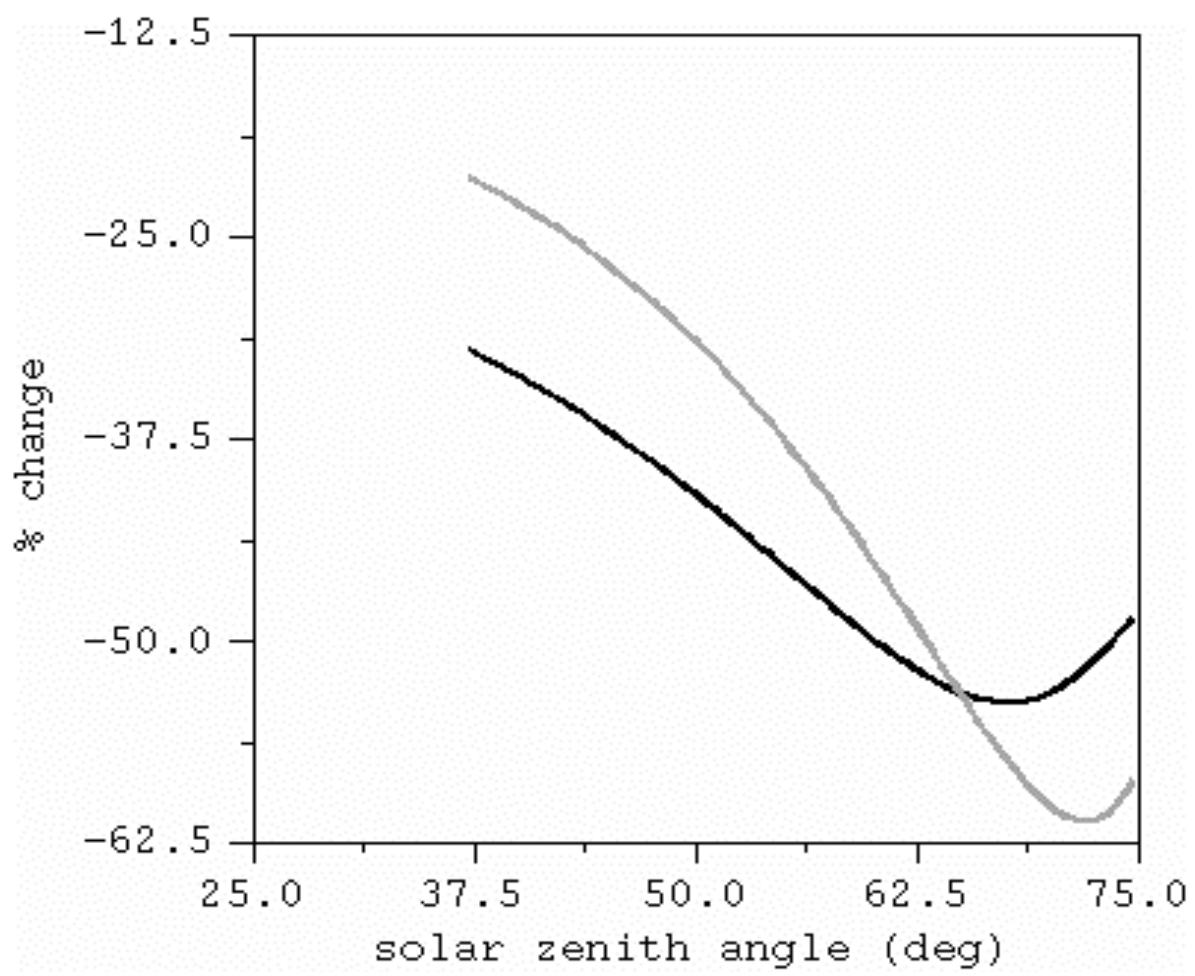

Fig. 8. (c) Percent change in the photolysis rates for the reaction $\mathrm{O}_{3} \rightarrow \mathrm{O}(1 \mathrm{D})$ (gray line) and $\mathrm{NO}_{2}$ (black line) (as functions of solar zenith angle), as a result of introducing a smoke layer into the model photolysis rate calculations.

\section{ACPD}

6, 3227-3264, 2006

\section{Forest fire smoke plume}

V. R. Kotamarthi et al.

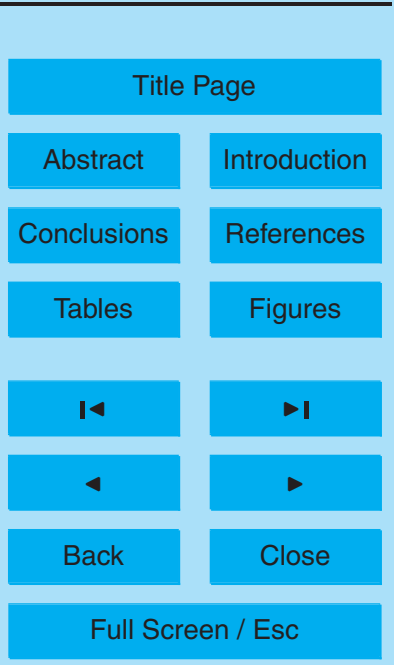

Printer-friendly Version

Interactive Discussion 


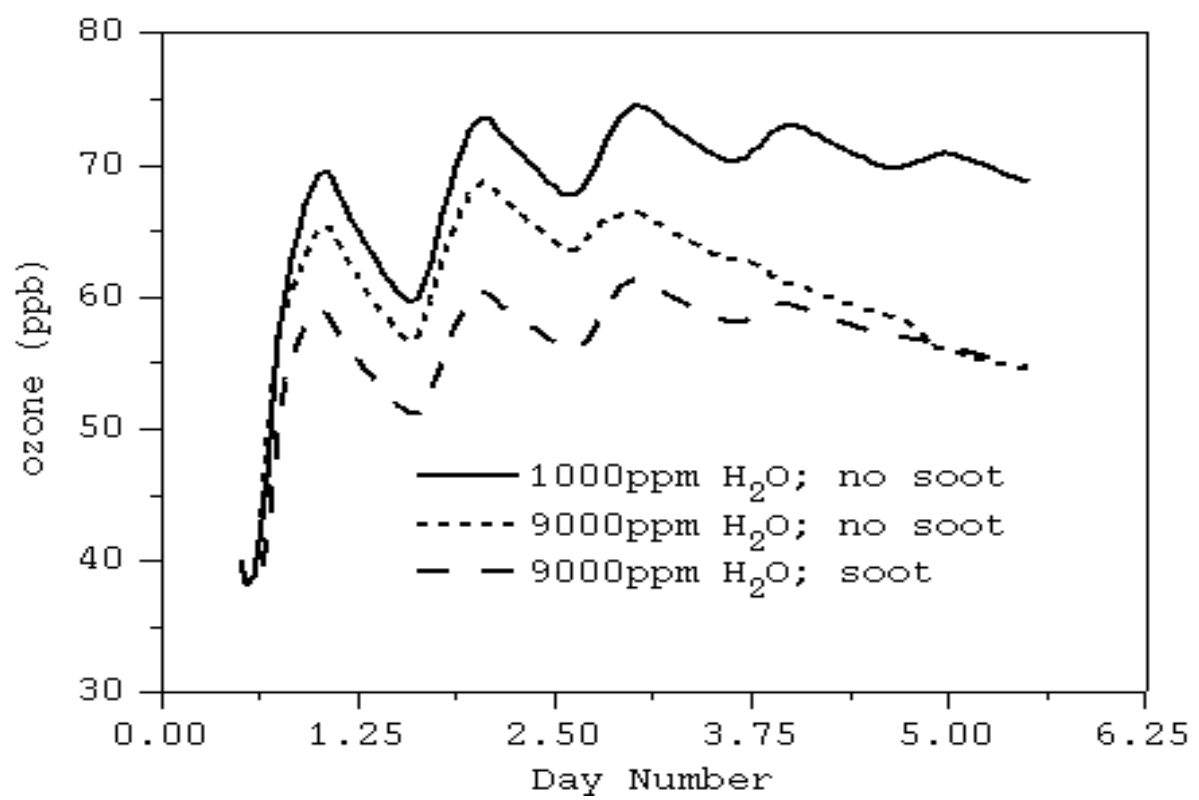

Fig. 9. Ozone mixing ratio results from model calculations over a five-day period over Phoenix, starting at 04:00 p.m. on 15 May and ending at 04:00 p.m. on 20 May. The solid line represents the calculations with no smoke layer and water vapor at $1000 \mathrm{ppm}$. The short-dashed line represents the case with no smoke layer and high water vapor $(9000 \mathrm{ppm})$ in the plume. The long-dashed line is for the case with high water vapor (9000 ppm) and a layer of smoke introduced to reduce the photolysis rates in the model. The ambient $\mathrm{NO}_{\mathrm{x}}$ in all these calculations is fixed at 200 pptv.

\section{ACPD}

6, 3227-3264, 2006

Forest fire smoke plume

V. R. Kotamarthi et al.

Title Page

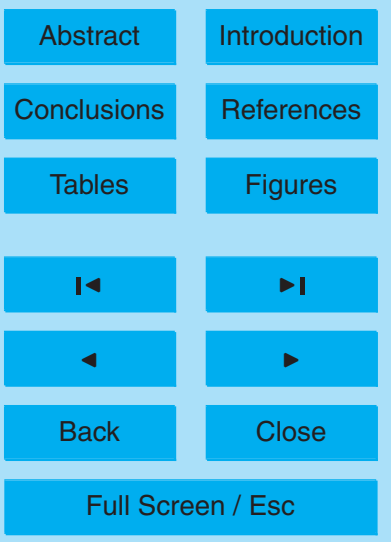

Printer-friendly Version

Interactive Discussion 


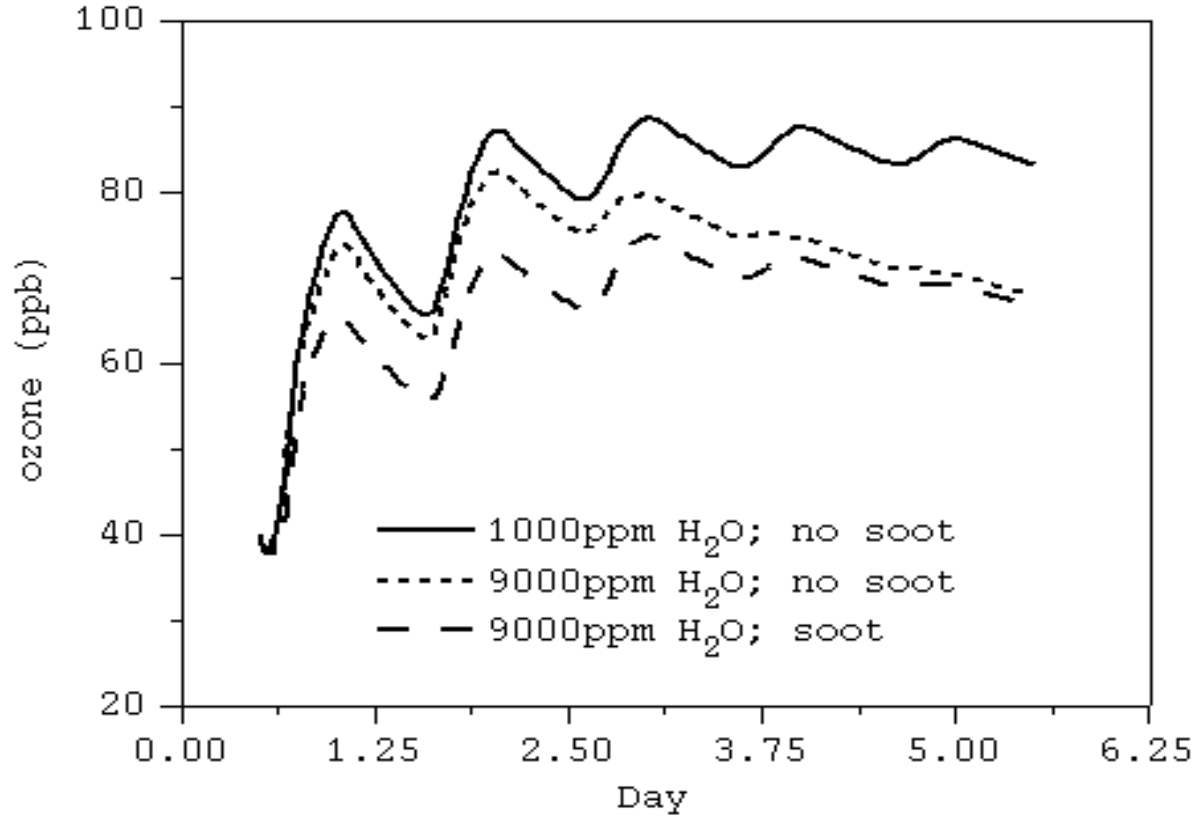

Fig. 10. Ozone concentration results from model calculations over a five-day period over Phoenix, starting at 04:00 p.m. on 15 May and ending at 04:00 p.m. on 20 May. The solid line represents the calculations with no smoke layer and water vapor at $1000 \mathrm{ppm}$. The shortdashed line represents the case with no smoke layer and high water vapor (9000 ppm) in the plume. The long-dashed line is for the case with high water vapor $(9000 \mathrm{ppm})$ and a layer of smoke introduced to reduce the photolysis rates in the model. The ambient $\mathrm{NO}_{\mathrm{x}}$ in all these calculations is fixed at $1.5 \mathrm{ppbv}$.

\section{ACPD}

6, 3227-3264, 2006

Forest fire smoke plume

V. R. Kotamarthi et al.

Title Page

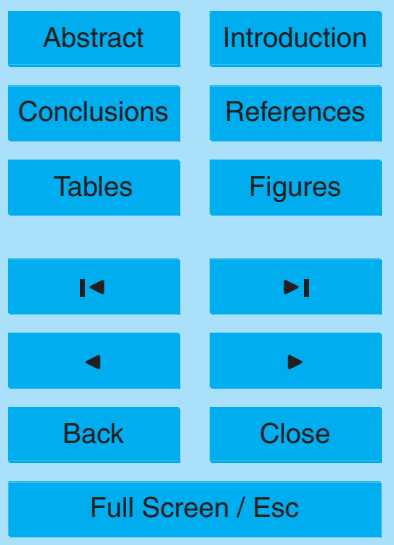

Printer-friendly Version

Interactive Discussion 


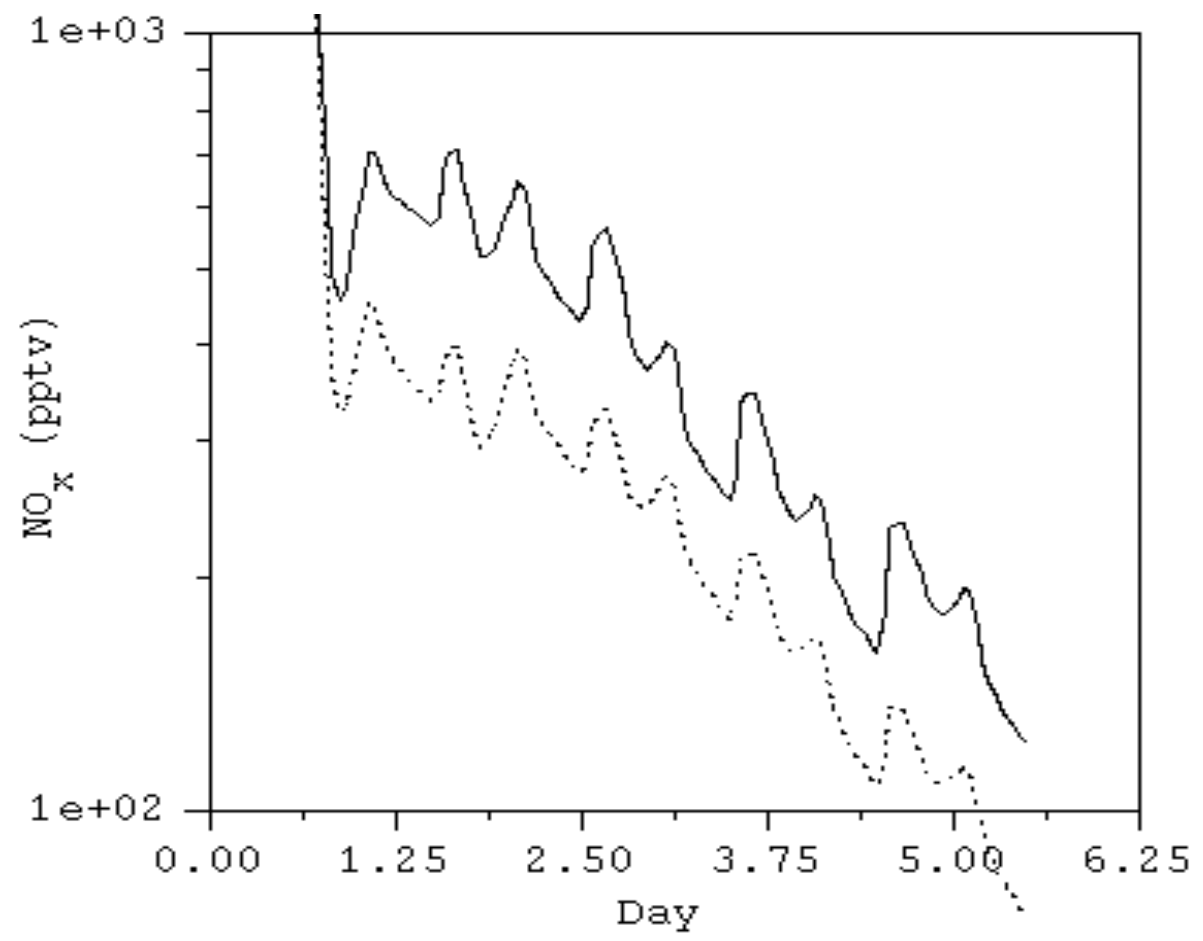

Fig. 11. Variations in the plume $\mathrm{NO}_{x}$ mixing ratios for the two ambient $\mathrm{NO}_{\mathrm{x}}$ conditions assumed for the calculations. The solid line is for calculations with high ambient $\mathrm{NO}_{x}(1.5 \mathrm{ppbv})$, and the dotted line shows results for low ambient $\mathrm{NO}_{\mathrm{x}}(200 \mathrm{pptv})$.

\section{6, 3227-3264, 2006}

\section{Forest fire smoke plume}

V. R. Kotamarthi et al.

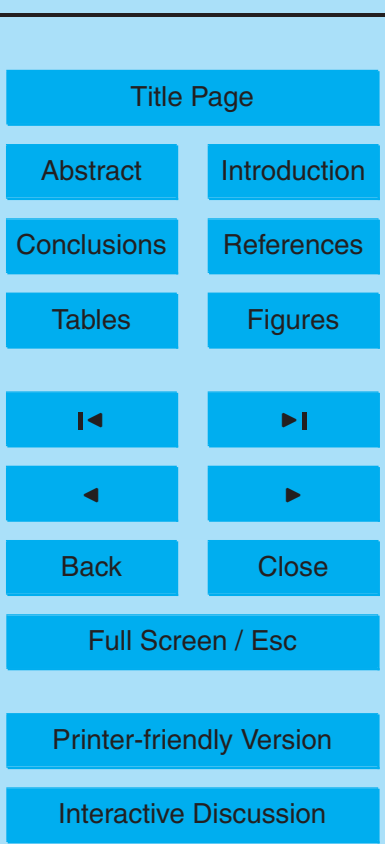




\section{ACPD}

6, 3227-3264, 2006

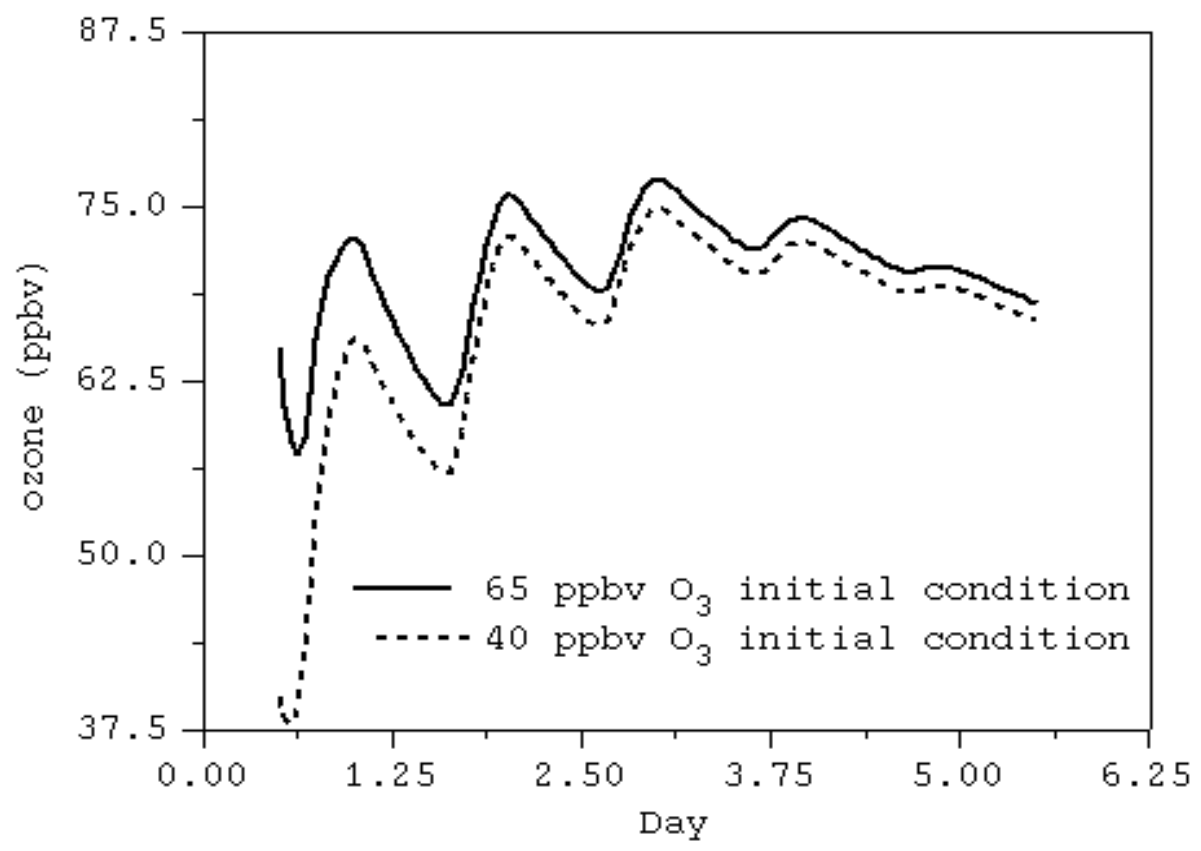

\section{Forest fire smoke plume}

\section{R. Kotamarthi et al.}

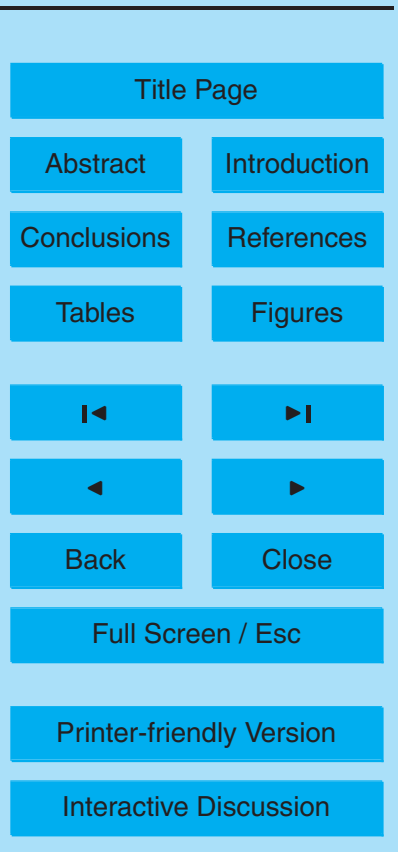

Fig. 12. Sensitivity of final ozone to initial ozone mixing ratios assumed for the plume. The solid line has an initial ozone mixing ratio of $65 \mathrm{ppbv}$, and the dotted line has an initial ozone mixing ratio of $40 \mathrm{ppbv}$. 


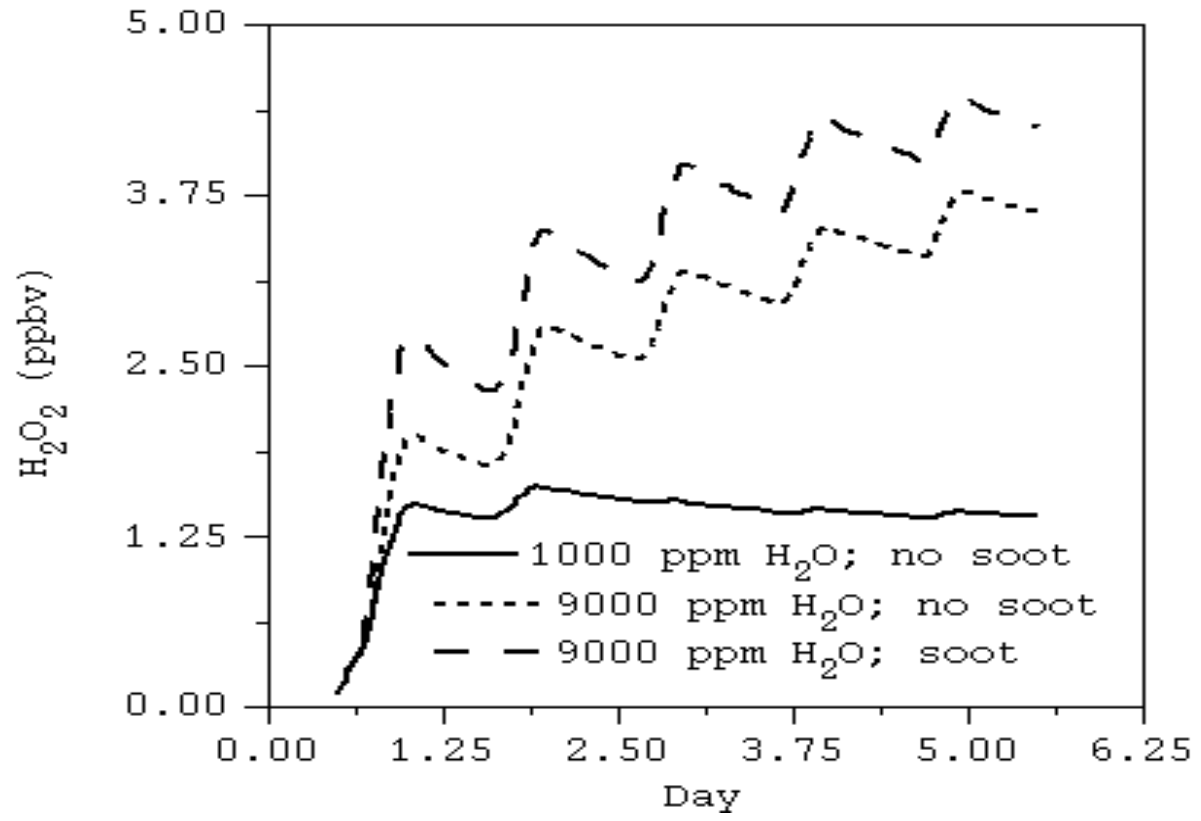

Fig. 13. Calculated hydrogen peroxide $\left(\mathrm{H}_{2} \mathrm{O}_{2}\right)$ in the model under three different sets of conditions. The solid line is for the case with low water vapor $(1000 \mathrm{ppm})$ and no soot layer, the short-dashed line is for the case with high water vapor $(9000 \mathrm{ppm})$ and no soot layer, and the long-dashed line is for the case with high water vapor $(9000 \mathrm{ppm})$ and a soot layer that acts to reduce the photolysis rates.
6, 3227-3264, 2006

\section{Forest fire smoke plume}

\section{R. Kotamarthi et al.}

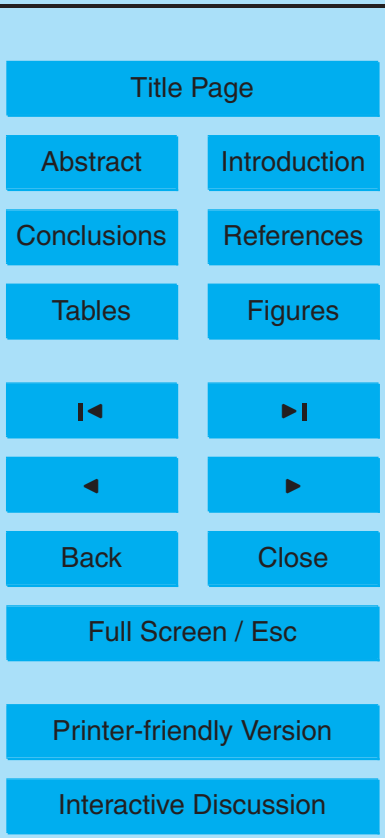

